\title{
The Synergy of Living and Water Wall in Indoor Environment-Case Study in City of Brno, Czech Republic
}

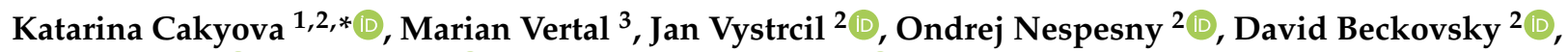 \\ Ales Rubina ${ }^{4}\left({ }^{\circ}\right.$, Jan Pencik ${ }^{2}$ a and Zuzana Vranayova ${ }^{3}$ \\ 1 Center for Research and Innovation in Construction, Faculty of Civil Engineering, Technical University of \\ Košice, Vysokoškolská 4, 04200 Košice, Slovakia \\ 2 Institute of Building Structures, Faculty of Civil Engineering, Brno University of Technology, Veveři 331/95, \\ 60200 Brno, Czech Republic; vystrcil.j@fce.vutbr.cz (J.V.); nespesny.o@fce.vutbr.cz (O.N.); \\ beckovsky.d@fce.vutbr.cz (D.B.); pencik.j@vutbr.cz (J.P.) \\ 3 Institute of Architectural Engineering, Faculty of Civil Engineering, Technical University of Košice, \\ 04200 Košice, Slovakia; marian.vertal@tuke.sk (M.V.); zuzana.vranayova@tuke.sk (Z.V.) \\ 4 Institute of Building Services, Faculty of Civil Engineering, Brno University of Technology, Veveři 331/95, \\ 60200 Brno, Czech Republic; rubina.a@fce.vutbr.cz \\ * Correspondence: katarina.cakyova@tuke.sk; Tel.: +421-944-731-360
}

\section{check for} updates

Citation: Cakyova, K.; Vertal, M.; Vystrcil, J.; Nespesny, O.; Beckovsky, D.; Rubina, A.; Pencik, J.; Vranayova, Z. The Synergy of Living and Water Wall in Indoor Environment-Case Study in City of Brno, Czech Republic. Sustainability 2021, 13, 11649. https://doi.org/10.3390/su132111649

Academic Editors: Luis Pérez-

Urrestarazu, Panayiotis A. Nektarios and Katia Perini

Received: 10 September 2021

Accepted: 17 October 2021

Published: 21 October 2021

Publisher's Note: MDPI stays neutral with regard to jurisdictional claims in published maps and institutional affiliations.

Copyright: (c) 2021 by the authors. Licensee MDPI, Basel, Switzerland. This article is an open access article distributed under the terms and conditions of the Creative Commons Attribution (CC BY) license (https:// creativecommons.org/licenses/by/ $4.0 /)$.
Abstract: The indoor environment that surrounds us and the elements in it affect not only our mood but also the air quality. Vegetation elements are currently more popular, especially for their aesthetic value but also because of the fact that they affect the physical parameters of the indoor environment such as temperature and humidity. Water elements are a similar example. The presented paper combines these two elements to achieve the best possible level of thermal comfort. Experimental verification of the influence of the living wall on air temperature and humidity took place during the heating season in the city of Brno in the space of the university, while three scenarios were created: the effect of the living wall in a semi-open space, an enclosed space, and a space with a water wall with regulated water temperature. The potential of the water wall is determined based on experimental verification in laboratory conditions. The results show that the synergy of the living and water wall in the indoor space may eliminate the risk of too-low humidity during the heating season.

Keywords: living wall; water wall; thermal comfort; water consumption; experimental measurement; heating season

\section{Introduction}

In the world of rapid urbanization and pressure on space, as a consequence, urban areas must provide adequate space for people to live in. Studies have shown a beneficial relationship between the natural environment, such as green spaces, and health [1,2]. Exposure to the natural environment has been associated with better mental health [3] and lower risk of morbidity and mortality [4,5]. Various studies deal with the relationship between the natural environment and improvement of social interaction [6], decreasing stress levels [7], and lower exposure to air pollution [8] or noise [9]. Similarly to green bodies, blue bodies that are represented by rivers, lakes, and fountains, or other artificial water elements may also have a positive impact on human wellbeing [10]. In particular, studies have found relationships between blue spaces and increased physical activity [11], improved mental health [3], and well-being [12,13] but also social interaction [14]. The synergy of green and blue spaces in the urban environment also proves to be beneficial in the fight against the so-called urban heat islands (UHI), which the urban areas face more often due to climate change and human activities [15-18]. Most of the studies deal with a cooling effect in combination with green and blue spaces by evapotranspiration, which is the sum of evaporation and plant transpiration from Earth's land and water surface to the atmosphere. The cooling effect of blue-green space has been recognized as a promising 
approach to mitigating urban heat islands (UHI) [19]. Evaporative cooling might be one of the highly efficient methods of passive cooling for urban spaces and buildings [20].

In the context of high urbanization [21] and spatial requirements of the population, based on the fact that people spend about $80-95 \%$ of their time inside buildings [22], the inclusion of green construction solutions, such as green roofs and facades [23], as well as indoor green and blue elements, is currently a trend in building design. The use of previous findings regarding urban green and blue bodies may also lead to the development of the use of natural elements in indoor environments. The living and water walls represent the most commonly used natural elements in building interiors [24]. As in the case of exterior elements, in the interior, these elements have the potential to improve the physiological and psychological health of people $[25,26]$, especially in school and work environments [27]. Students who are exposed to the natural environment report low levels of stress, fatigue, health complaints, and better attention [28,29]. Studies [30,31] have also shown that patients exposed to the natural environment recover faster and spend less time in hospitals. These psychological benefits might be related to the so-called biophilia concept (i.e., a preference for interacting in the natural environment as a consequence of our evolutionary development) and based on theories of restorative effects [32]. With the onset of the COVID-19 pandemic in 2020, society faced new situations, and many people faced forced isolation, which led to negative emotions of fear, disappointment, and insecurity. The survey [33] across the countries showed a positive influence of greenery and resulted in a shift of the participants' perception about the beneficial contribution of plants to the emotional welfare of inhabitants. Nearly $40 \%$ of participants declared a stronger motivation for having a higher number of plants at home. It turned out that the presence of greenery in the interior reduced the level of stress and depression and increased positive mood during the COVID-19 confinement period.

In recent years, the development and scientific interest in interior greenery has increased significantly. The interior greenery is not only represented by plants grown in pots but also by so-called green walls or living walls [34]. Today, there are many studies that define different systems and designs of these elements [34-37]. It is obvious that indoor greenery offers several benefits, such as producing oxygen through photosynthesis [38] and affecting the physical parameters of indoor air quality, mainly temperature and humidity [34,38-40], $\mathrm{CO}_{2}$ concentration [41], and acoustics [39]. However, the use of green walls in the interior may lead to increased humidity, which can pose a risk associated with mold problems, especially in humid and hot climates [36]. A study conducted by Hollands and Korjenic [42] shows an improvement of hygrothermal comfort in schools and offices. In addition, this study shows that the improvement of hygrothermal comfort has significantly reduced the absence due to illness of employees and increased cost savings based on the lower absence rate. The study shows that the vertical indoor greenery has a potential to improve indirect economic effects in the context of reduced sick leave in offices. Although the interest of researchers in investigating the effect of green walls in the indoor environment is high, most studies focus on the effect in a hot climate during cooling season [43], while the effect during the heating season in a colder climate is not well-studied.

As living walls, water features such as fountains and pools but also vertical water features are more and more commonly parts of building interiors, especially for their decorative character. However, compared to green walls, the effect of water elements on physical parameters of the indoor environment has not been sufficiently investigated [44]. The design of water elements in the interior may vary, either in shape or material. Water walls are most often used in the interior for the smaller space requirements required for their installation. In this case, water flows over the solid material and forms a thin film on it, which is in direct contact with the air, while water circulates in that system and its temperature is not adjusted. As in the case of outdoor water elements, internal water elements are used mainly in the context of evaporative cooling, because of which the air temperature decreases and water temperature increases $[45,46]$. The evaporation process 
is also associated with a change in the state of humidity, which increases. This can cause unpleasant air conditions, especially in warm and humid climates $[47,48]$. It follows that the evaporative cooling potential of water walls is more suitable for hot and dry climates. On the other hand, there is an assumption that with the regulation of the temperature of the water flowing in the system, it is possible to use the water wall with greater flexibility and adapt its use to the state of the air in the indoor environment [49]. If the water in the system is cooled below the air dew point, condensation will occur, dehumidifying the air in the room [44,50]. Conversely, if the water in the system is heated and maintained at a stable temperature, which will be similar to the air temperature, evaporation will occur, which will increase the humidity, and at the same time, the air in the indoor environment will not be cooled [51]. A stable water temperature in the system also reduces the risk of Legionella bacteria occurrence, which increases with increasing water temperature [52].

This paper focuses on the effect of a living wall on air physical parameters in the indoor environment during the heating season in the city of Brno, the Czech Republic. Temperature and humidity were monitored in semi-open and closed spaces for one month in February 2021. The humidification capacity of a water wall with controlled water temperature was defined by an equation based on laboratory measurements. Subsequently, this equation was applied using the measured data obtained by monitoring the living wall in the closed space. In addition to the physical parameters of the indoor microclimate, water consumption during the selected period is also monitored. As the synergy of living and water walls in the interior has not been sufficiently researched so far, the presented paper fills the gap of knowledge. It aims to determine the efficiency of a green wall in different types of space as well as to define the area of the water wall for a specific size of space with respect to thermal comfort during the heating season in the city of Brno.

\section{Materials and Methods}

\subsection{Research Methodology}

To determine the influence of the living and water wall on the physical parameters of the indoor environment (temperature and humidity), the experimental in situ verification of the green wall and the laboratory conditions for the water wall were chosen. In both cases, these were full-scale models. The effect of the living wall on the indoor environment was recorded during the heating period, specifically from 1 February to 1 March 2021. The heating season in the Czech Republic, according to government regulations, begins on 1 September, if the outdoor average air temperature drops below $13{ }^{\circ} \mathrm{C}$ for two consecutive days and no further temperature rise is expected. To determine the distribution of humidity and temperature through the living wall, the boundary conditions were monitored and recorded in close proximity to the wall in the vertical direction. In addition to monitoring of the boundary conditions in the proximity of the living wall, boundary conditions were also recorded at the distance of two meters from the living wall. The effect of the water wall on air parameters was monitored at different boundary conditions in the climatic chamber. The obtained data were analyzed and then the humidification capacity of the water wall was determined, which is quantified by the general equation of evaporation rate and shows the dependence between the evaporation rate, air temperature, and relative humidity. The obtained equation was subsequently used to determine the interaction of green and water walls by virtual application in the building interiors. Measured boundary conditions from the experimental verification of the effect of the living wall on air and humidity temperature are used as input values (Figure 1).

A total of three scenarios are created. In the case of Scenario 1, the influence of the living wall on physical parameters of the indoor microclimate (temperature and humidity) is monitored in a semi-open space without building modifications. In Scenario 2, the interior is modified, and a wooden structure with a cover foil is built to define the action area of the green wall. In Scenario 3, the synergy of water and living walls in the defined space is considered, and thus the water wall is implemented in the interior theoretically 
using the determined equation from laboratory measurements and measured data from Scenario 2, specifically the data from the sensor located $2 \mathrm{~m}$ from the living wall.

In addition to the influence of living and water walls on the indoor microclimate, the water consumption of both walls is determined as well.

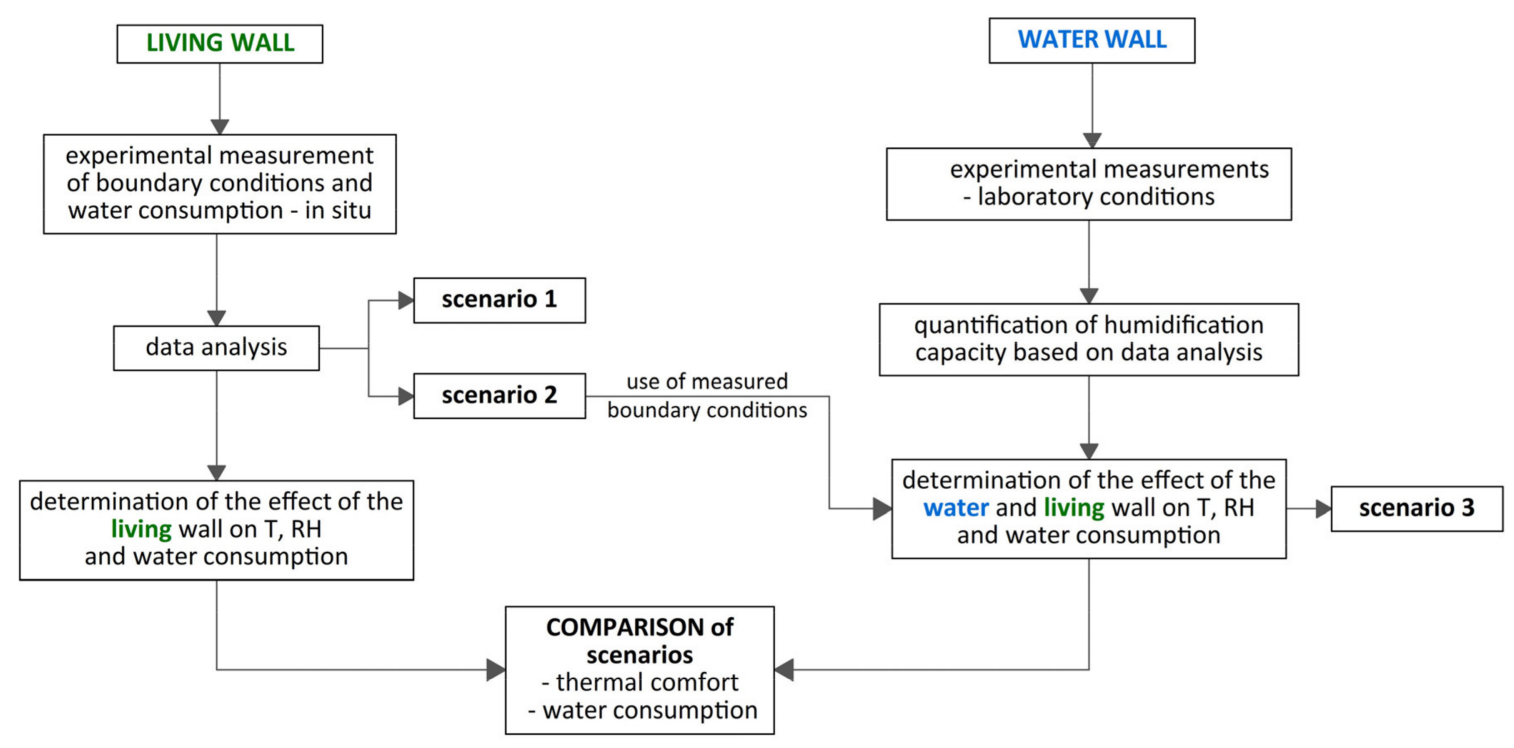

Figure 1. Research scheme.

\subsection{Living Wall}

\subsubsection{Location}

The experimental living wall was built in July 2020 at the Institute of Building Structures, Faculty of Civil Engineering, Brno University of Technology. The historical building was built in the 19th century and is not insulated. The living wall is located on the third floor in the corridor tract (Figure 2), which is open from one side. In this space, there is a steel panel radiator, which is connected to the central heating system that works every working day. Experimental measurements were performed at the end of the second third of the heating season; the radiator in the corridor area has a constant heating power during the season, and as it was the same during the scenarios, its impact was neglect. The walls of the corridor and the ceiling are covered with lime-cement plaster; the floor is tiled with ceramic tiles with grout with a hydrophobic effect. The corridor is illuminated through a window with double-insulating glass oriented south-east and with dimensions of $2.05 \times 2.65 \mathrm{~m}(\mathrm{w} \times \mathrm{h})$. The window was not opened during the test period. The space of the corridor is without mechanical ventilation; therefore, the humidity level could not be controlled and regulated before the start of experimental measurements, and the state of indoor air is mainly influenced by the state of exterior air. As can be seen from Figure 2, the corridor space is delimited mainly by the interior and thus there were minimal thermal fluctuations between the test room of the corridor and the rest of the interior. In the case when the space is closed (Scenarios 2 and 3), the area that is in contact with the exterior is $12 \%$ of the total area of the corridor space. 


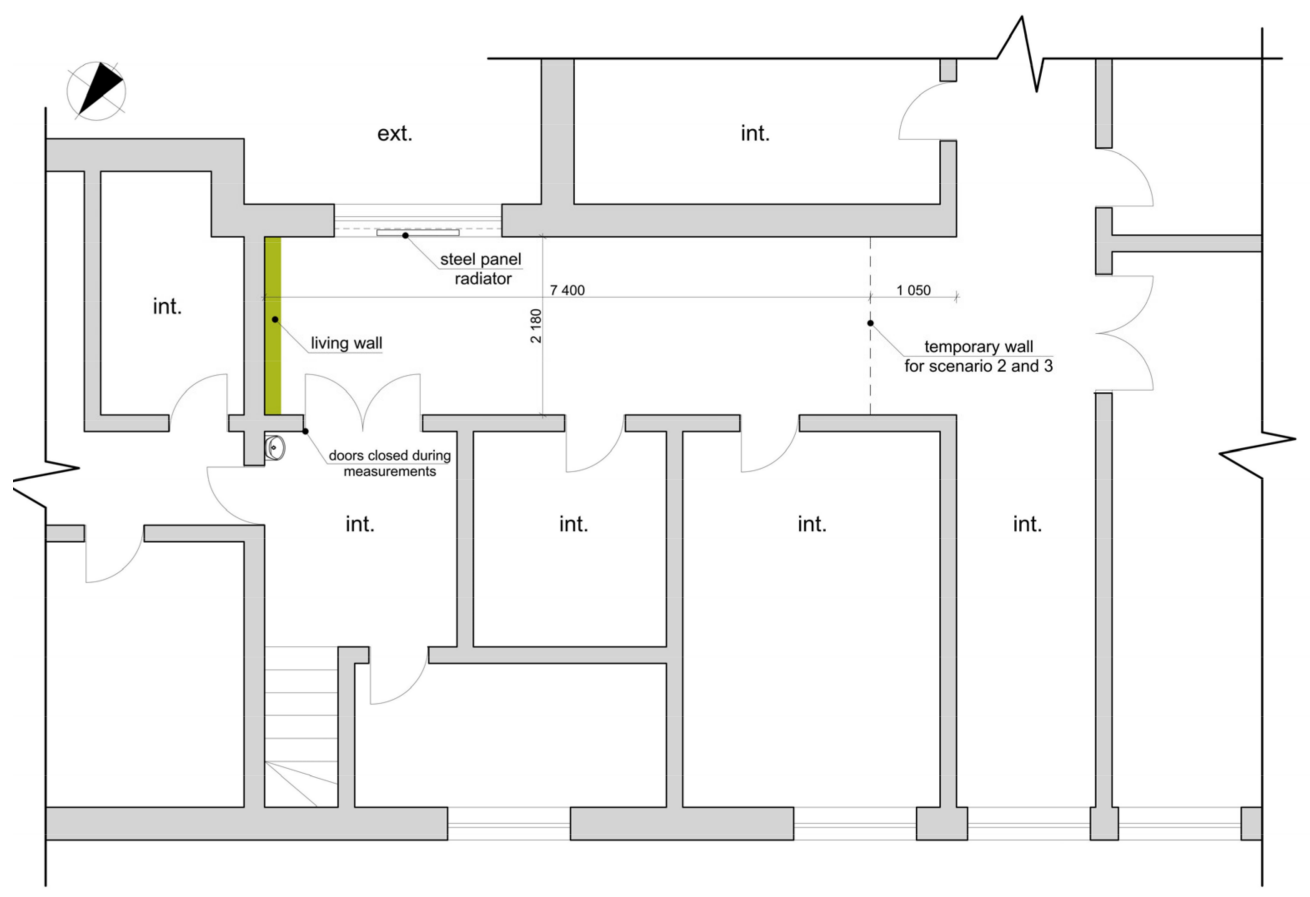

Figure 2. Section of floor plan of third floor of Faculty of Civil Engineering building with location of green wall.

The city of Brno is located in the south-eastern part of the Czech Republic (coordinates: $49^{\circ} 11^{\prime} 33^{\prime \prime} \mathrm{N}, 16^{\circ} 36^{\prime} 30^{\prime \prime}$ E). According to the World Map of Köppen-Geiger Climate Classification, the climate of Brno is the oceanic climate $(\mathrm{Cfb})[53,54]$, which is characterized as mild with no dry season and with warm summers. The coldest months are December (long-term avg. temp. $-0.3^{\circ} \mathrm{C}$ ), January (long-term avg. temp. $-1.7^{\circ} \mathrm{C}$ ), and February with a long-term average temperature of $0.2^{\circ} \mathrm{C}$. January and February are the months with the lowest amount of precipitation of 27 and $25 \mathrm{~mm}$, respectively. Even though a long-term average relative humidity for January, February, and December is relatively high ( $84 \%$, $79 \%$, and $86 \%$, respectively) [55], due to low temperatures, the humidity ratio is low, and after heating the air to the interior temperature, the relative humidity often drops to a low value [56], which may cause diseases or irritations of skin, eyes, and upper respiratory tracts [57]. Due to the common problem with low humidity during the heating season, the measurement of the effect of the living wall in the month of February was chosen, specifically in the period from 01.02. to 01.03.2021. Figure 3 shows the average hourly weather data for February 2021 in Brno. The data are obtained from a professional weather station located in the campus of the Faculty of Civil Engineering, which records data in minute intervals [58]. During this period, the lowest average hourly temperature was $-11.0^{\circ} \mathrm{C}$, which was measured on February 15 th. The highest average hourly temperature was recorded on 26 February, specifically $13.1^{\circ} \mathrm{C}$. The average temperature for this period was $0.25 \pm 4.9^{\circ} \mathrm{C}$, which approximately corresponds to the long-term average temperature for February in Brno. The relative humidity during the selected period ranged from $41.7 \%$ to $100 \%$, and the average value was $91.9 \pm 12.7 \%$, which is a significantly higher value compared to the long-term average RH for the city of Brno. The average globe irradiance during this period was $68.74 \mathrm{~W} / \mathrm{m}^{2}$ with a maximum of $566 \mathrm{~W} / \mathrm{m}^{2}$ and the amount of precipitation was $30.5 \mathrm{~mm}$. 


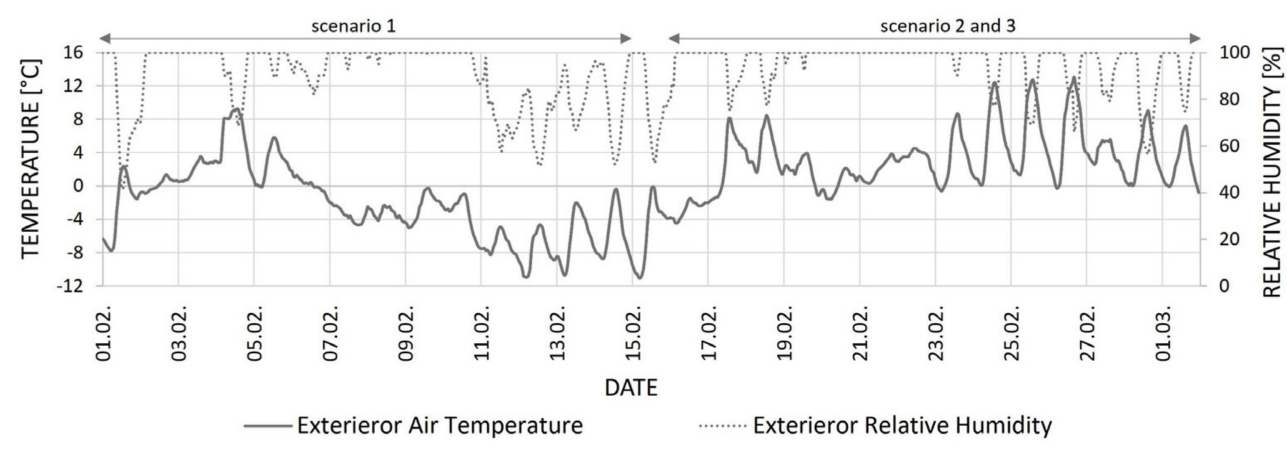

(a)

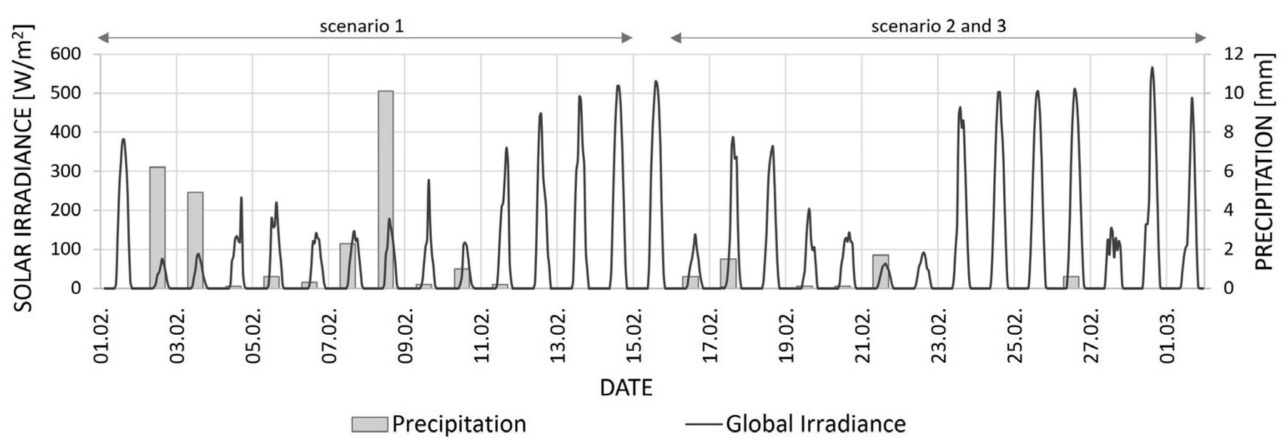

(b)

Figure 3. Outdoor boundary conditions for all scenarios shown as hourly average values of weather data in city of Brno during the selected period of 01.02.-01.03.2021 obtained from a professional weather station located in the campus of Faculty of Civil Engineering [58]: (a) temperature and relative humidity; (b) precipitation and solar irradiance.

\subsubsection{Construction Process}

The dimensions of the living wall are $2.18 \times 2.3 \mathrm{~m}(\mathrm{w} \times \mathrm{h})$; thus, the area of the living wall is $5.0 \mathrm{~m}^{2}$ (Figure $4 \mathrm{~b}$ ). The lower edge of the living wall is $1.4 \mathrm{~m}$ from the floor and the upper edge is $0.1 \mathrm{~m}$ from the ceiling. The system solution of company FloraUrbanica [59] was used as the construction solution, which is characterized as a lego system-panels are vertically locked into each other. The first step was to install underlying plywood with a waterproof layer, which is anchored to a load-bearing wall. Subsequently, the panels were fixed to a wooden chipboard, a total of 13 rows, while, in one row, there were three panels with a capacity of six (left), three (middle), and six (right) flowerpots. The panels were connected in the vertical direction. These panels were made of polypropylene and aluminum, which ensures long life and $100 \%$ recyclability. Flowerpots, which are squareshaped with dimensions of $13 \times 13 \times 13 \mathrm{~cm}$, were inserted in these panels; the total number of flowerpots was 195 ( 15 flowerpots in one row). The most-used plants were Philodendron Grand Brasil (approx. 20\%), Philodendron Scandens (approx. 20\%), Aglaonema Silver Queen (approx. 15\%), Beaucarnea Recurvata (approx. 10\%), or Monstera Obliqua and Deliciosa (approx. $5 \%$ ) and others. A total of approximately 12 species of plants were used (Figure 4a). As a growing medium, the mineral hydroponic substrate with a grain fraction of size $3 / 8$ was used. The main components of the hydroponic substrate were pumice stone (approx. 60\%), zeolite granules, and lightweight expanded clay aggregate. 


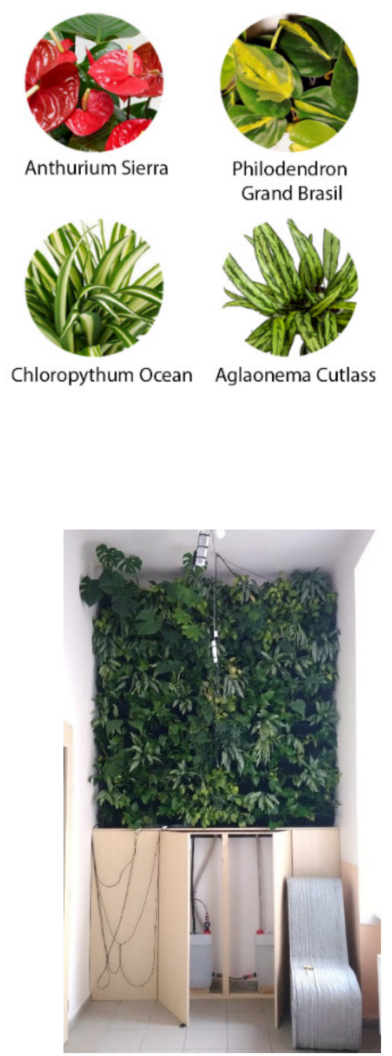

(b)
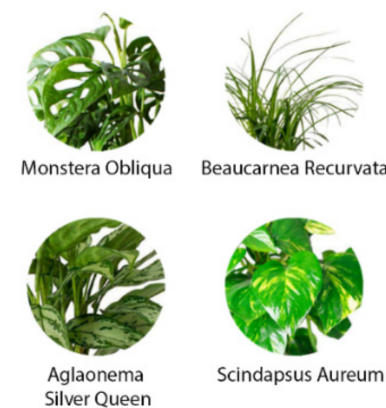

Beaucarnea Recurvata
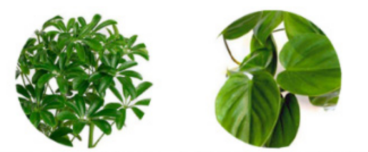

Schefflera Arboric Philodendron Scandens

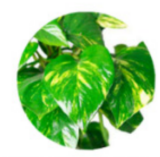

Scindapsus Aureum

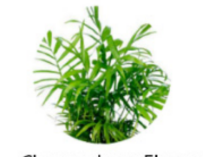

Chamaedoera Elegans

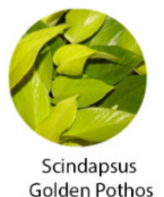

(a)

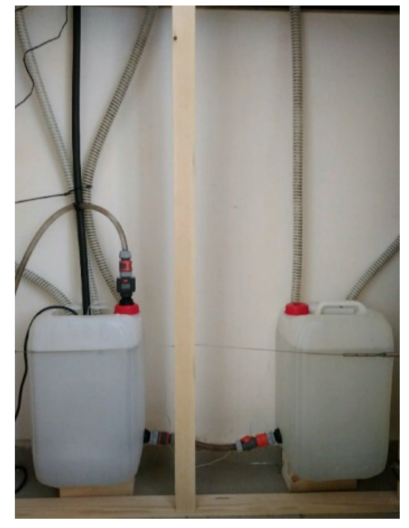

(c)

Figure 4. (a) Most frequently used plant species; (b) frontal view of experimental living wall; (c) detailed view of irrigation system.

\subsubsection{Irrigation System}

The plants were grown with the use of a sub-irrigation system when the plant sucks water from the bottom of the panels. The water tank is stored in a cabinet under the living wall and consists of two plastic tanks (Figure 4c); the volume of each one is $25 \mathrm{~L}$. The tanks are connected at the bottom by a pipe. A submersible pump is in one of the tanks; after it is switched on, the water is pumped into the upper part of the wall by the irrigation pipe. First, the water irrigates the plants located the highest and the excess water flows by gravity into the lower parts of the wall. At the end of the irrigation process, the excess water drains back into the plastic tank through the return pipes. The connecting pipe ensures that the water level is equal in both tanks after some time.

Part of the irrigation system is a return pipe, with a total of five pipes-two for the panels with six flowerpots and one for the panel with three flowerpots. As already mentioned, the return pipe serves to supply excess water to the plastic tank. This system prevents the accumulation of water at the lower part of the wall as well as excessive water consumption as the excess water accumulates back in the water tank and is used for irrigation again.

The water tank is connected to a source of drinking cold water via a supply pipe. Water is added to the plastic tank manually as appropriate. The pump is connected to a mobile application that ensures automatic irrigation, or remote start, if necessary. In the winter season, the frequency of the irrigation system starts is at least twice a week, or more often after visual inspections. The duration of the system irrigation is $30 \mathrm{~min}$ and is performed in the morning (7:30-8:00 a.m.).

As noted earlier, the entire irrigation system is placed in a cabinet, which was made from birch as the final surface treatment. This solution and the choice of light colors of the surrounding walls emphasized the decorative character of the living wall even more. 


\subsubsection{Measuring Infrastructure}

To define the influence of the living wall on physical parameters of the indoor environment, Comet DigiL/M digital sensors were installed. The sensors record the air temperature and relative humidity; their specification is shown in Table 1.

The three sensors $(1 \mathrm{~A}, 1 \mathrm{~B}$, and $1 \mathrm{C})$ are located close to the living wall, specifically $200 \mathrm{~mm}$ from the panel along the vertical axis of the wall. These sensors are arranged in the vertical direction (each $575 \mathrm{~mm}$ ), which made it possible to monitor the change in temperature and $\mathrm{RH}$ depending on the height. The position of the fourth sensor (2B) is oriented at the intersection of the horizontal and vertical axes of the living wall and is located $2000 \mathrm{~mm}$ from the sensor 1B. Figure 5 shows the vertical and horizontal spatial arrangement of the sensors.

Table 1. Specification of used sensors for recording of living wall influence on indoor microclimate.

\begin{tabular}{ccccc}
\hline \multicolumn{2}{c}{ Parameter } & Device & Range & Deviation \\
\hline \multirow{2}{*}{ Air } & humidity & Comet DigiL/M & 0 to $100 \% \mathrm{RH}$ & $\pm 1.8 \% \mathrm{RH}$ (at nominal temperature \\
& temperature & & -10 to $+60{ }^{\circ} \mathrm{C}$ & $+23{ }^{\circ} \mathrm{C}$ and RH 0-90\%) \\
& & $\pm 0.4{ }^{\circ} \mathrm{C}$ \\
\hline
\end{tabular}

Data collection from sensors is realized by multiloggers Comet. The freely available Comet vision software was used for the communication and set of data loggers. Recording of measured parameters was performed in 5 min time steps.

To monitor the water consumption of the living wall, a digital flow meter with the accuracy of $0.1 \mathrm{~L}$ was installed on the supply pipe to the water tank. Before irrigation, the water in the tanks is refilled to a pre-specified level. Subsequently, one hour after the end of the irrigation process, the water in tanks is replenished to the same level, and the amount of water consumed during irrigation is read from the flow meter. To determine the water consumption, this activity must be repeated after each irrigation.

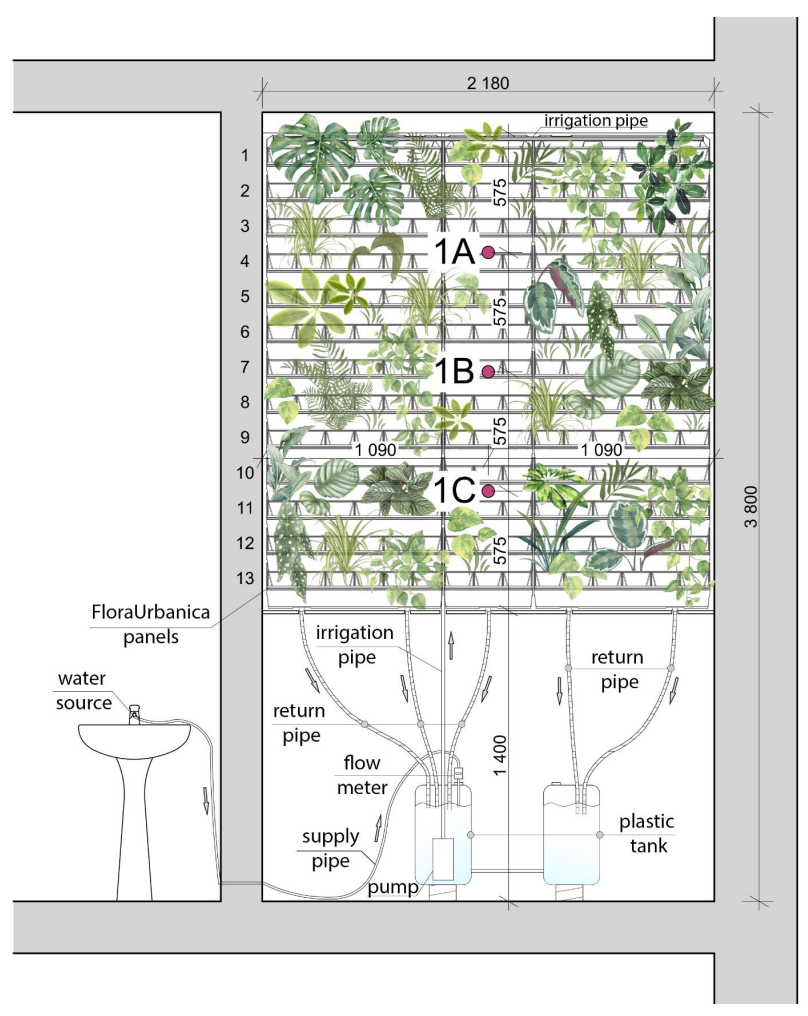

(a)

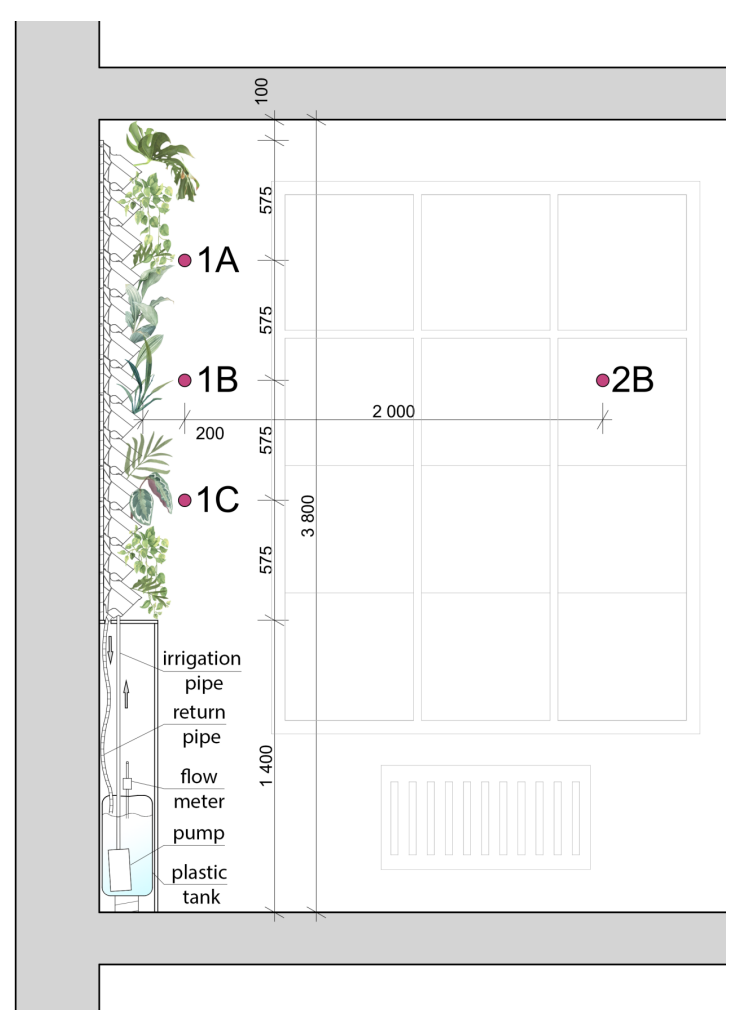

(b)

Figure 5. Schematic view on living wall, irrigation system, and measuring infrastructure: (a) front view; (b) cross-section. 


\subsection{Water Wall}

\subsubsection{Laboratory Conditions and Water Wall Prototype Design}

To quantify the evaporation capacity of the water wall, the experimental verification under laboratory conditions was chosen, specifically in the climatic chamber (Figure 6a) with a floor area of $6.32 \mathrm{~m}^{2}$ and height of $2.85 \mathrm{~m}$. The climatic chamber is located in the laboratory of the Faculty of Civil Engineering, Technical University of Košice, and is characterized by its ability to set and maintain steady boundary conditions (temperature range from -20 to $+125^{\circ} \mathrm{C}$, relative humidity from $20 \%$ to $95 \%$ ) for the entire duration of the measurement. The walls are made from stainless steel, so the moisture buffer effect by the surrounding surface can be neglected and the clean humidification potential of the water wall can be determined.

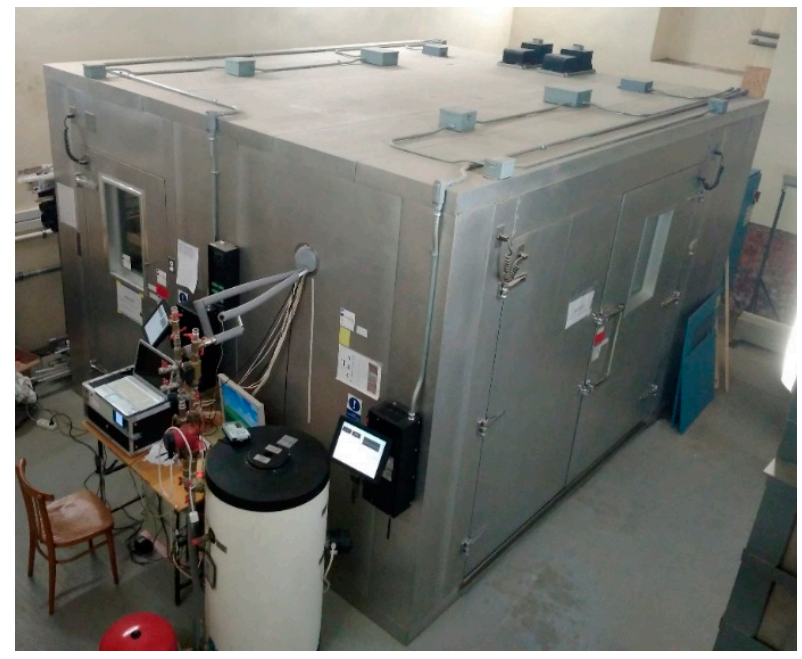

(a)

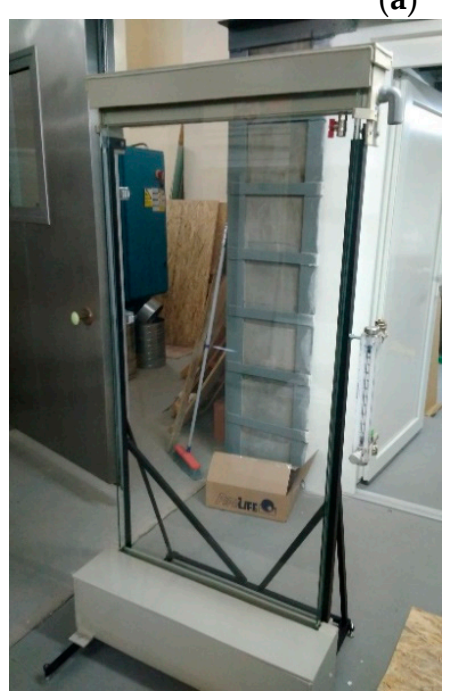

(c)

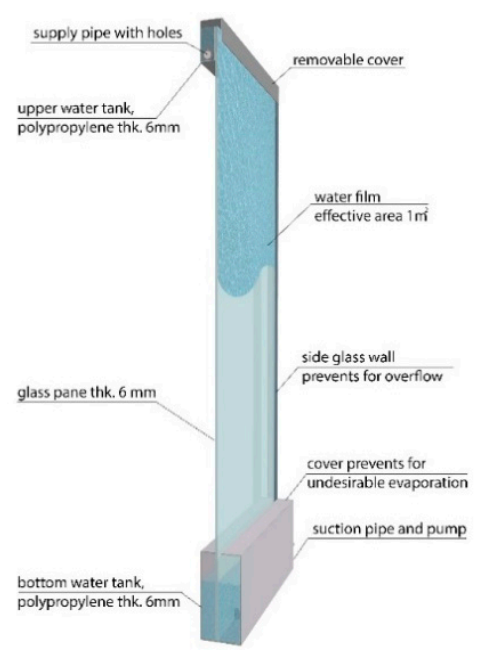

(b)

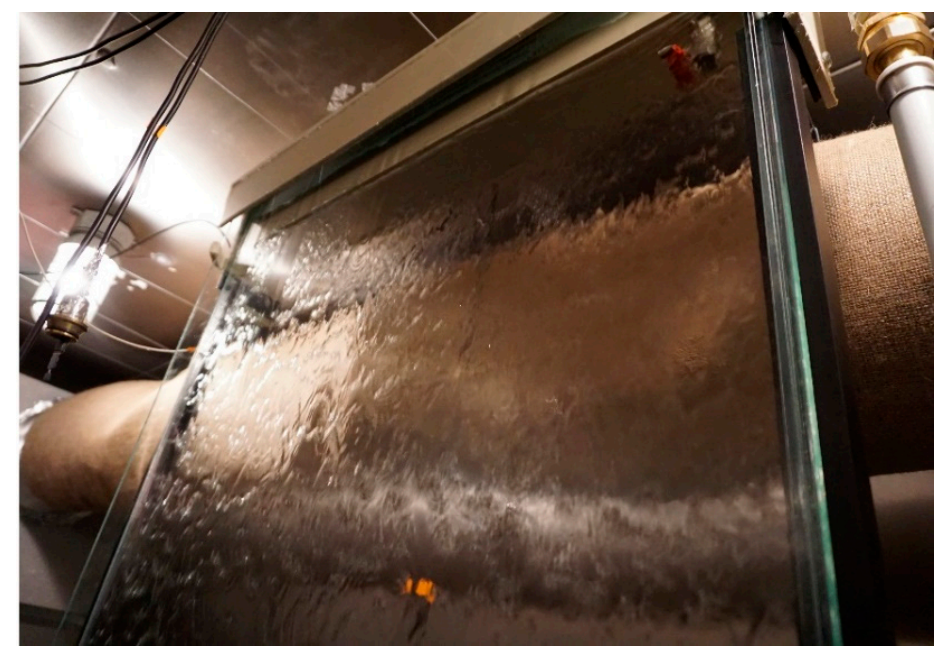

(d)

Figure 6. Experimental setup for determination of humidification capacity of water wall: (a) exterior view on climatic chamber; (b) design of experimental water wall prototype; (c) final experimental water wall prototype; (d) falling water film on water wall prototype.

For the experimental verification, the full-scale water wall prototype was designed (Figure 6b) and built (Figure 6c). The water wall prototype consists of two collecting water tanks with a rectangular shape made of $6 \mathrm{~mm}$ thick polypropylene material. The water is pumped from the lower water tank to the upper water tank, in which the perforated pipe is located [60]. This ensures a fluent and continuous distribution of water throughout the tank. Subsequently, the water falls over the overflow edge made up of a glass pane, flows 
down the surface of the glass, and creates a continuous falling water film (Figure $6 \mathrm{~d}$ ). The dimensions of the falling water film are $0.71 \times 1.42 \mathrm{~m}(\mathrm{w} \times \mathrm{h})$, and the area is $1 \mathrm{~m}^{2}$ [51].

\subsubsection{Measuring System}

The final water wall prototype was adapted and placed on an elevated wooden structure in the climatic chamber. The adaptation involved attaching a metering cylinder to the lower water tank and components such as valves, a flow meter, and a plate heat exchanger were added in the system. The plate heat exchanger was connected to a tank with hot water located outside the climatic chamber. The thermostat ensured the heating of the water to approximately $23{ }^{\circ} \mathrm{C}$ during all measurements. During experimental measurements, the flow rate was $450 \mathrm{~L} / \mathrm{h}$, which was found to be the optimum flow rate during past experiments [61].

To quantify the evaporation rate of the water wall, the system based on the principle of communicating vessels (Figure 7) is used. The glass tank with two supply pipes (one for air and one for water) is placed on a laboratory scale (RADWAG with $6000 \mathrm{~g}$ limit and accuracy of $0.01 \mathrm{~g}$ ). The end of the air supply pipe is placed at the water level in the measuring cylinder and the end of the water pipe supply $150 \mathrm{~mm}$ lower than the air supply pipe. At the moment when the evaporation from the falling film appears, the water level in the measuring cylinder decreases. Due to this fact, pressure equalization occurs, and water flows from the glass tank placed on the scale into the measuring cylinder until it reaches the level of the air supply pipe. With this system, the evaporation rate is recorded accurately and continuously in time.

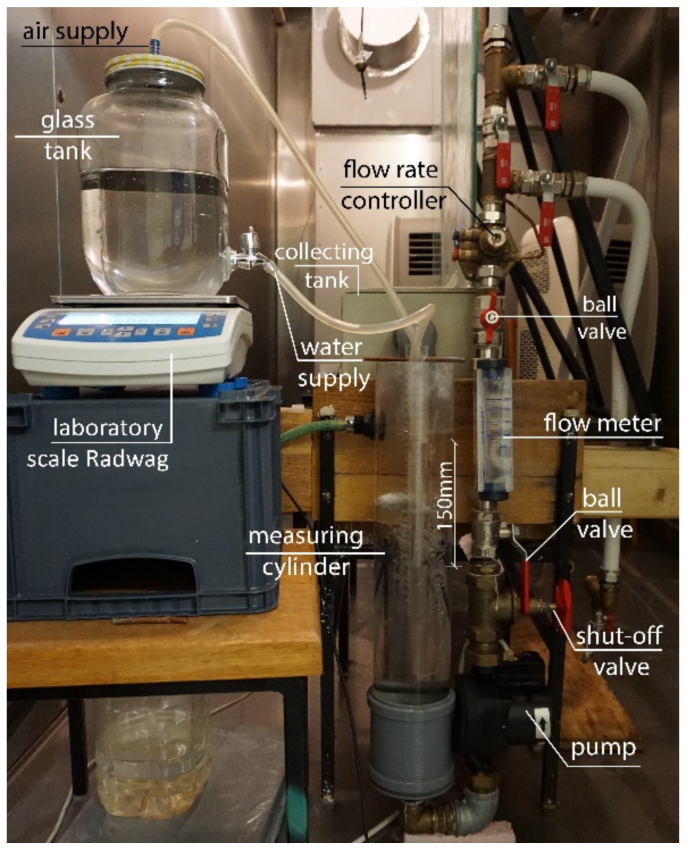

(a)

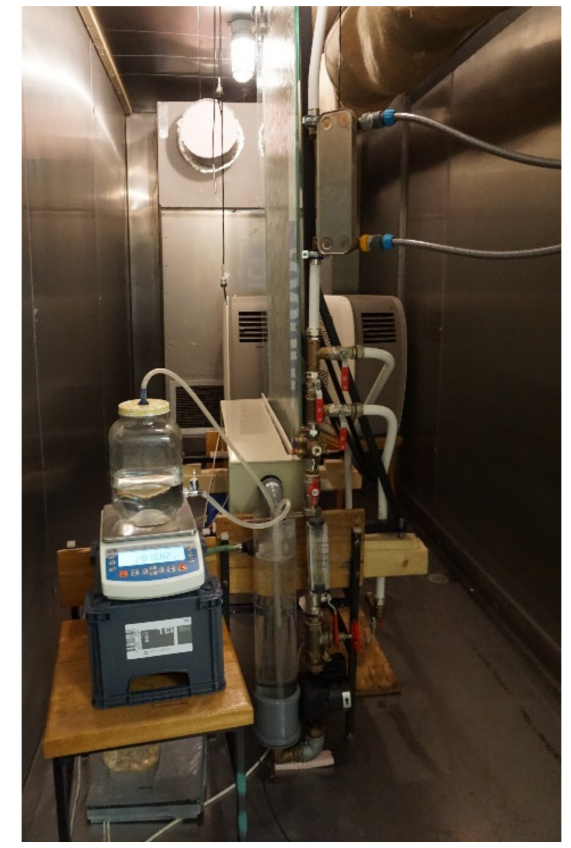

(b)

Figure 7. The measuring system of water wall humidification capacity: (a) Detailed view and description of measuring system; (b) overall view of experimental water wall and measuring infrastructure located in climatic chamber.

\subsubsection{Measuring Infrastructure}

In the chamber, a total of seven sensors were installed to record the boundary conditions. The temperature of the water was measured by NTC sensor FN $0001 \mathrm{~K}$ (Ahlborn, Holzkirchen, Germany). Two sensors measured the water temperature at the lower tank, and two measured the water temperature in the upper tank. From the sensors, the mean water temperatures for the upper and lower tank were determined. Additionally, two sen- 
sors of FHAD 46-C0 type (Ahlborn, Holzkirchen, Germany) were installed to measure the temperature and relative humidity of air in front of the water film and one sensor of FHAD 46-C0 type behind the glass. Limiting deviations of the sensors are described in Table 2.

Data collection from sensors is made by a control unit Ahlborn (Ahlborn, Holzkirchen, Germany). The AMR Win Control software version 8.2.1.0 was used for communication and setting of the measurements. Recording of measurements was performed in 2 min time steps.

Table 2. Specification of used sensors for recording boundary conditions during water wall testing.

\begin{tabular}{ccccc}
\hline \multicolumn{2}{c}{ Parameter } & Device & Range & Deviation \\
\hline Water & temperature & $\begin{array}{c}\text { NTC sensor } \\
\text { FN 0001 K }\end{array}$ & 0 to $70{ }^{\circ} \mathrm{C}$ & $\pm 0.2 \mathrm{~K}$ \\
\multirow{2}{*}{ Air } & $\begin{array}{c}\text { humidity } \\
\text { temperature }\end{array}$ & FHAD 46-C0 & $\begin{array}{c}10 \text { to } 90 \% \mathrm{RH} \\
5 \text { to } 60{ }^{\circ} \mathrm{C}\end{array}$ & $\begin{array}{c} \pm 2.0 \% \mathrm{RH} \text { at nominal temperature } \\
\left(+23{ }^{\circ} \mathrm{C}\right)\end{array}$ \\
\hline
\end{tabular}

\section{Results and Discussion}

\subsection{Living Wall}

The measurement of physical parameters of the air in the building interior with the presence of a living wall took place during the heating season, from 1 February to 1 March 2021, specifically, two weeks for Scenario 1 (1 February-14 February 2021); on 15 February, a wooden structure with a cover foil was built, which defined and closed a space with a volume of $61.3 \mathrm{~m}^{3}$. Subsequently, a two-week measurement was performed for Scenario 2 (16 February-1 March 2021). The measurements took place more than half a year after the installation of the living wall, and therefore it can be considered as well-rooted. In addition, due to the pandemic situation in the Czech Republic, during this period there was a minimum of people on the premises of the University and thus the influence of people on the humidity and air temperature in the space can be neglected.

As the corridor is illuminated by the window with an eastern orientation, the resulting values are evaluated without the data measured in time from 8:00-10:00, and thus without two hours in the morning when the temperature and humidity were affected by direct sunlight falling on the sensors.

\subsubsection{Scenario 1}

In the case when humidity distribution in the air in the vertical direction is monitored, the relative humidity for sensor $1 \mathrm{C}$ (lower part of the living wall) is in the range of $26.2 \%$ to $39.1 \%$, while the mean value of relative humidity is $33.0 \%$. In the case that the sensor is located in the upper part of the living wall (1A), relative humidity varies in the range of $25.3-35.9 \%$, and the mean relative humidity measured by this sensor is $30.2 \%$. The results show that the mean relative humidity in the lower part is $2.8 \%$ higher than the average humidity measured in the upper part of the living wall. This difference is caused by the fact that the mean temperature measured in the lower part of the living wall (sensor 1C) was $1.1^{\circ} \mathrm{C}$ lower than the measured mean temperature in the upper part of the living wall. The comparison of the humidity ratio in the upper and lower parts shows minimum differences; the mean humidity ratio in the lower part is $0.1 \mathrm{~g} / \mathrm{kg}$ higher than in the upper part of the living wall.

The distribution of relative humidity, temperature, and humidity ratio in the horizontal direction does not show significant differences when comparing the mean values measured in close proximity (sensor 1B) and at a distance of $2 \mathrm{~m}$ from the living wall (sensor $2 \mathrm{~B}$ ). The mean relative humidity is $0.3 \%$ higher near the living wall than two meters from it, while the mean measured temperatures are identical. Thus, the average humidity ratio is $0.1 \mathrm{~g} / \mathrm{h}$ higher near the living wall than two meters from it.

Figure 8 shows the course of selected physical parameters during the monitored period. As can be seen, relative humidity does not exceed $40 \%$ for any sensor. The figure 
also shows the maximum measured temperatures (almost $27^{\circ} \mathrm{C}$ ) and the minimum values of relative humidity (less than 20\%) of the air, which were recorded during morning hours. As already mentioned, these data are not considered in the overall evaluation.

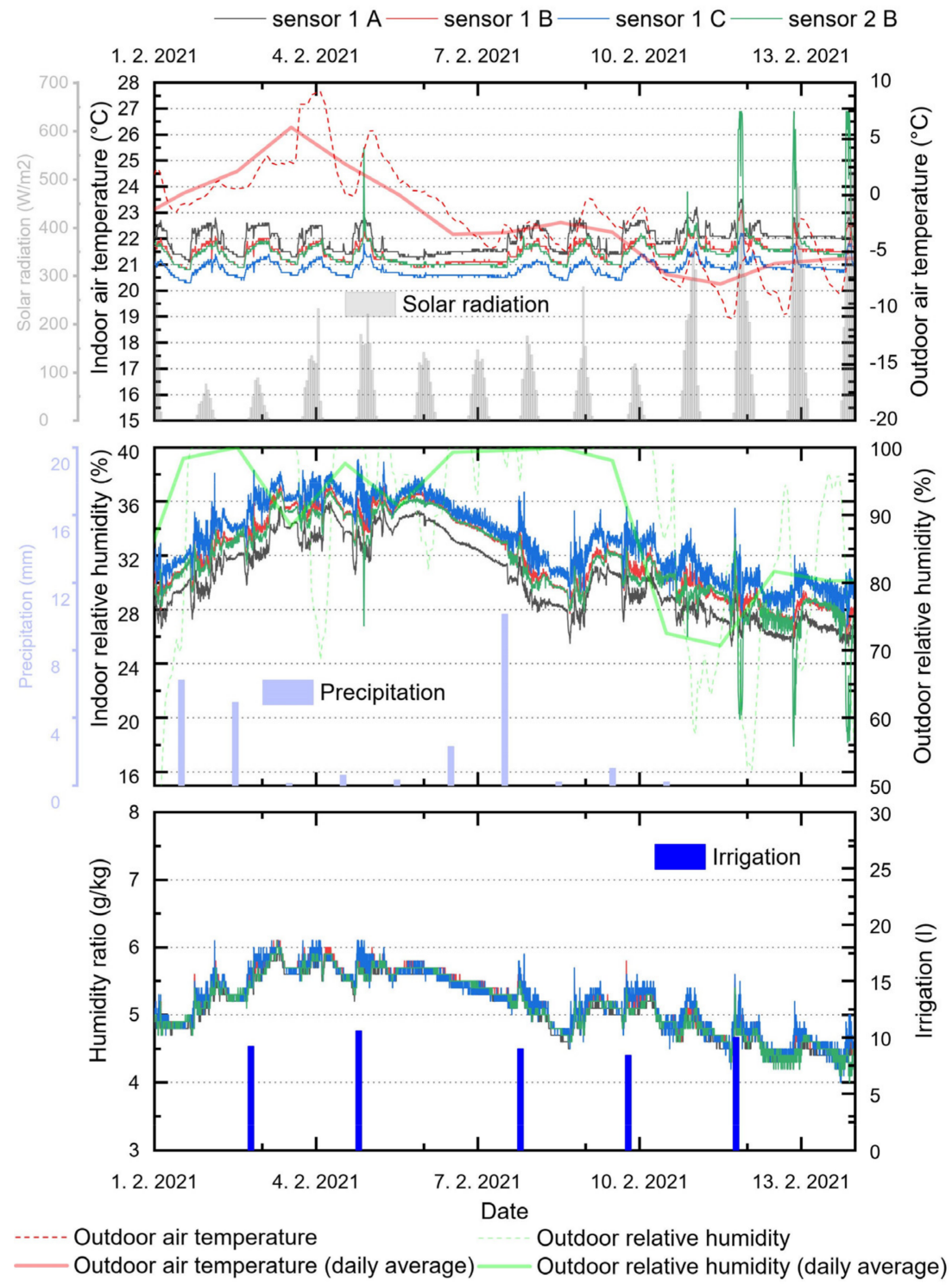

Figure 8. Course of selected measured parameters during Scenario 1: semi-open space and outdoor boundary conditions.

\subsubsection{Scenario 2}

Monitoring of the humidity distribution in the vertical direction shows higher mean relative humidity in the lower part (Sensor 1C) by $2.8 \%$ than in the upper part (Sensor 1A) of the living wall. The mean measured relative humidity in the lower part is $46.2 \%$ and varies in the range of $33.8-53.8 \%$. In the lower part of the living wall, the mean relative humidity of $43.4 \%$ was recorded with the maximum measured relative humidity of $51.7 \%$ and the minimum measured relative humidity of $31.9 \%$. The difference in relative humidity in the lower and upper part is also based on the fact that the mean temperature measured in the lower part of the living wall (Sensor $1 \mathrm{C}$ ) was $0.7^{\circ} \mathrm{C}$ lower than the measured mean temperature in the upper part of the living wall. The comparison of humidity ratio in the upper and lower part shows minimal differences; the mean humidity ratio in the lower part was $0.1 \mathrm{~g} / \mathrm{kg}$ higher than in the upper part of the living wall. 
Similarly to Scenario 1, the distribution of relative humidity, temperature, and humidity ratio in the horizontal direction when comparing the mean values measured in close proximity (sensor 1B) and at a distance of $2 \mathrm{~m}$ from the living wall (sensor 2B) do not show significant differences. The mean relative humidity is $0.7 \%$ higher near the living wall than two meters from it, while the mean measured temperatures are identical. Thus, the mean humidity ratio is $0.1 \mathrm{~g} / \mathrm{h}$ higher close to the living wall than two meters from it.

The courses of selected monitored parameters during the period from 16 February to 1 March are shown in Figure 9. As can be seen, relative humidity does not exceed 55\% for any sensor. Similarly to Scenario 1 , the maximum values for air temperature (over $27^{\circ} \mathrm{C}$ ) and minimum relative humidity (less than $35 \%$ ) measured in the morning hours are not included in the overall evaluation.

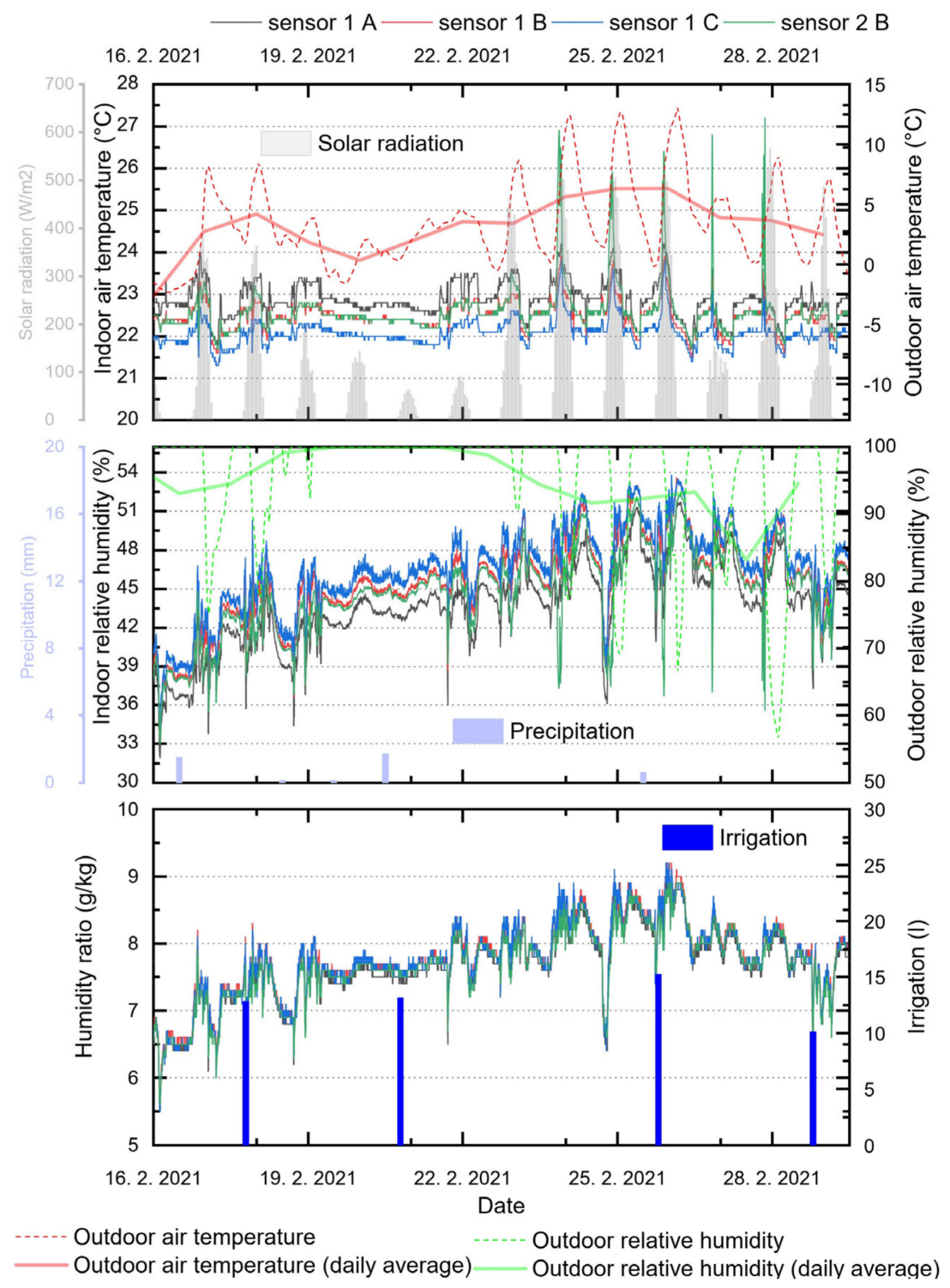

Figure 9. Course of selected measured parameters during Scenario 2: close space and outdoor boundary conditions.

The resulting data (Table 3 ) show that, by closing the space, the mean temperature increases by $1.1^{\circ} \mathrm{C}$ (by comparing Sensors $1 \mathrm{~B}$ and 2B). However, it should be noted that the increase in temperature during Scenario 2 is also based on the exterior temperature when the average exterior temperature was $3.1^{\circ} \mathrm{C}$, which represents an increase in the average exterior temperature by $5.3^{\circ} \mathrm{C}$ compared to Scenario 1 when the average exterior 
air temperature was $-2.2^{\circ} \mathrm{C}$. In Scenario 2 , the mean relative humidity near the living wall (Sensor 1B) increased by $13.5 \%$ and by $13.1 \%$ at a distance of two meters from the living wall (Sensor B). This is also related to the increase in the humidity ratio if the space is closed. The mean humidity ratio increases by $2.5 \mathrm{~g} / \mathrm{h}$ (by comparing sensors $1 \mathrm{~B}$ and $2 \mathrm{~B}$ ). Similar to the exterior temperature, relative humidity in the exterior was also higher during Scenario 2. Average exterior relative humidity increased by $5.8 \%$, from $89.4 \%$ (Scenario 1 ) to $95.2 \%$ (Scenario 2). This increase may have in part contributed to an increase in relative humidity during Scenario 2.

Table 3. Resulting measured values of selected physical air parameters for Scenarios 1 and 2 (without data measured in time from 8:00 to 10:00 a.m.).

\begin{tabular}{|c|c|c|c|c|c|c|c|c|c|c|c|c|c|}
\hline & & \multicolumn{4}{|c|}{ Temperature $\left({ }^{\circ} \mathrm{C}\right)$} & \multicolumn{4}{|c|}{ Relative Humidity (\%) } & \multicolumn{4}{|c|}{ Humidity Ratio (g/kg) } \\
\hline & & \multicolumn{4}{|c|}{ Sensor } & \multicolumn{4}{|c|}{ Sensor } & \multicolumn{4}{|c|}{ Sensor } \\
\hline & & $1 \mathrm{~A}$ & $1 \mathrm{~B}$ & $1 \mathrm{C}$ & $2 \mathrm{~B}$ & $1 \mathrm{~A}$ & $1 \mathrm{~B}$ & $1 \mathrm{C}$ & $2 \mathrm{~B}$ & $1 \mathrm{~A}$ & $1 \mathrm{~B}$ & $1 \mathrm{C}$ & $2 \mathrm{~B}$ \\
\hline \multirow{3}{*}{ Scenario 1} & $\operatorname{Max}$ & 23.4 & 22.8 & 22.2 & 25.8 & 35.9 & 37.2 & 39.1 & 36.9 & 5.9 & 6.1 & 6.1 & 6.1 \\
\hline & Min & 21.1 & 20.8 & 20.2 & 20.7 & 25.3 & 26.7 & 26.2 & 20.4 & 4.2 & 4.3 & 4.0 & 4.1 \\
\hline & Mean & $\begin{array}{c}21.9 \pm \\
0.4\end{array}$ & $\begin{array}{c}21.4 \pm \\
0.3\end{array}$ & $\begin{array}{c}20.8 \pm \\
0.3\end{array}$ & $\begin{array}{c}21.4 \pm \\
0.4\end{array}$ & $\begin{array}{c}30.2 \pm \\
2.9\end{array}$ & $\begin{array}{c}31.8 \pm \\
2.9\end{array}$ & $\begin{array}{c}33.0 \pm \\
2.8\end{array}$ & $\begin{array}{c}31.5 \pm \\
2.9\end{array}$ & $\begin{array}{c}5.1 \pm \\
0.5\end{array}$ & $\begin{array}{c}5.2 \pm \\
0.5\end{array}$ & $\begin{array}{c}5.2 \pm \\
0.5\end{array}$ & $\begin{array}{c}5.1 \pm \\
0.5\end{array}$ \\
\hline \multirow{3}{*}{ Scenario 2} & Max & 24.2 & 23.9 & 23.8 & 25.4 & 51.7 & 53.6 & 53.8 & 52.5 & 9.0 & 9.2 & 9.2 & 8.9 \\
\hline & Min & 21.7 & 21.5 & 21.3 & 21.7 & 31.9 & 33.2 & 33.8 & 33.1 & 5.5 & 5.6 & 5.5 & 5.6 \\
\hline & Mean & $\begin{array}{c}22.8 \pm \\
0.4\end{array}$ & $\begin{array}{c}22.5 \pm \\
0.3\end{array}$ & $\begin{array}{c}22.1 \pm \\
0.3\end{array}$ & $\begin{array}{c}22.5 \pm \\
0.3\end{array}$ & $\begin{array}{c}43.4 \pm \\
3.7\end{array}$ & $\begin{array}{c}45.3 \pm \\
3.7\end{array}$ & $\begin{array}{c}46.2 \pm \\
3.6\end{array}$ & $\begin{array}{c}44.6 \pm \\
3.6\end{array}$ & $\begin{array}{c}7.6 \pm \\
0.6\end{array}$ & $\begin{array}{c}7.7 \pm \\
0.6\end{array}$ & $\begin{array}{c}7.7 \pm \\
0.6\end{array}$ & $\begin{array}{c}7.6 \pm \\
0.6\end{array}$ \\
\hline
\end{tabular}

Although other studies [34,38,62] show significantly higher effects of the living wall on air temperature and relative humidity near the living wall, and at a certain distance from it, achieved results do not confirm this effect. The mean relative humidity near the living wall and at a distance of $2 \mathrm{~m}$ is higher by $0.3 \%$ and $0.7 \%$ for Scenarios 1 and 2, respectively. This difference is at the level of accuracy of the installed measuring equipment (Table 1) and therefore cannot be considered significant. It is similar in the case of temperature distribution in the horizontal direction, where the difference between the mean temperature near the wall and two meters from it is not demonstrated for any scenario. The difference in the temperature and relative humidity in the vertical direction shows more pronounced differences (Table 3), which is probably based on the natural flow of air around the wall. However, when comparing the humidity ratio, this difference is minimal; the mean humidity ratio is higher in the lower part of the living wall by $0.1 \mathrm{~g} / \mathrm{kg}$ for Scenarios 1 and 2 .

\subsection{Water Wall}

To determine the humidification capacity of the water wall with controlled water temperature, a total of 14 measurements were performed with two repetitions, and the evaporation rate was investigated for each measurement. During the measurements, air temperature varied from 19.2 to $28.3^{\circ} \mathrm{C}$ and relative humidity from $30.0 \%$ to $56.6 \%$ (Figure 10).

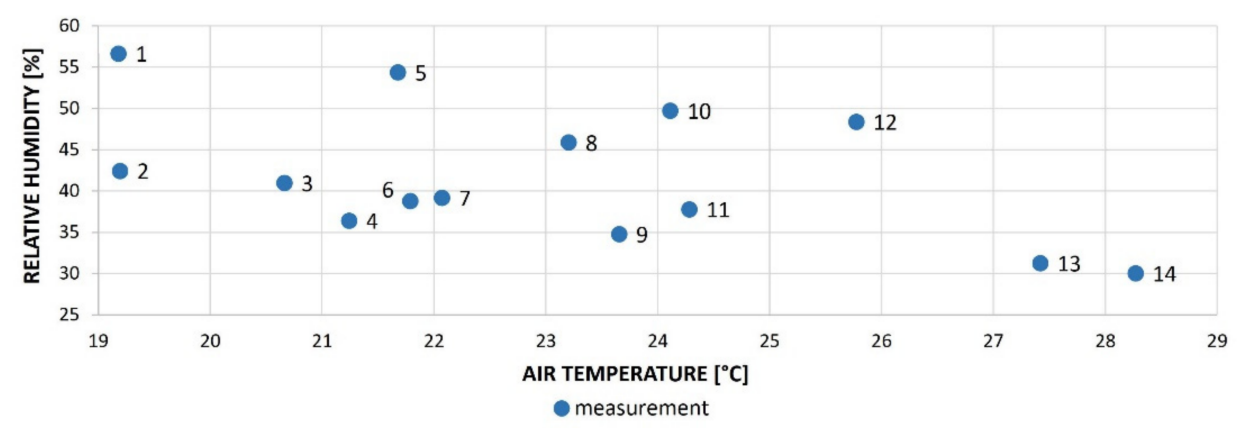

Figure 10. Scatter plot of boundary conditions during measurements. 
All experiments took $8 \mathrm{~h}$ and measurements were recorded in 2 min time steps. The obtained data from sensors were edited to mean values, so that the mean water temperature, air temperature, and relative humidity could be determined. The mean water temperature was $22.8 \pm 0.3{ }^{\circ} \mathrm{C}$ in the lower tank and $23.0 \pm 0.3^{\circ} \mathrm{C}$ in the upper tank. The evaporation rate was evaluated based on the weight decrease of water in the glass tank caused by the evaporation process in time. The minimum evaporation rate $(180.97 \mathrm{~g} / \mathrm{h})$ was observed during measurement No. 5 (air temperature $21.7^{\circ} \mathrm{C}$, relative humidity $54.4 \%$ ), the maximum evaporation rate $(293.87 \mathrm{~g} / \mathrm{h}$ ) during the measurement No. 13 (air temperature $27.4{ }^{\circ} \mathrm{C}$, relative humidity $31.3 \%$ ). The resulting values of the evaporation rate of the water wall prototype and boundary conditions during measurements are evaluated in Table 4.

To quantify the relationship between air temperature, relative humidity, and evaporation rate, OriginPro 9.0 software was used. The 3D scatter plot (Figure 11a) shows individual measurements in a spatial visualization.

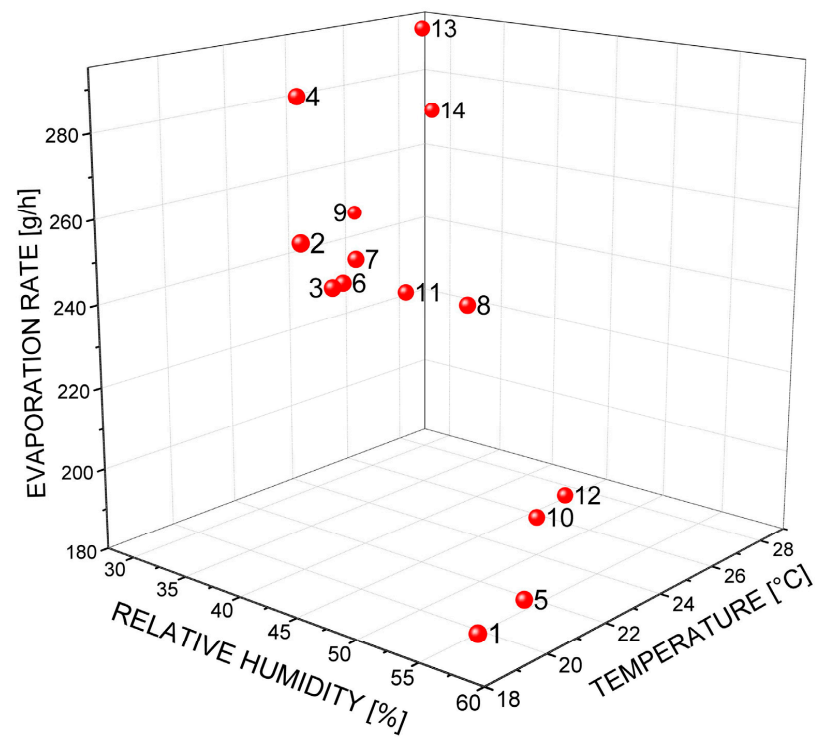

(a)

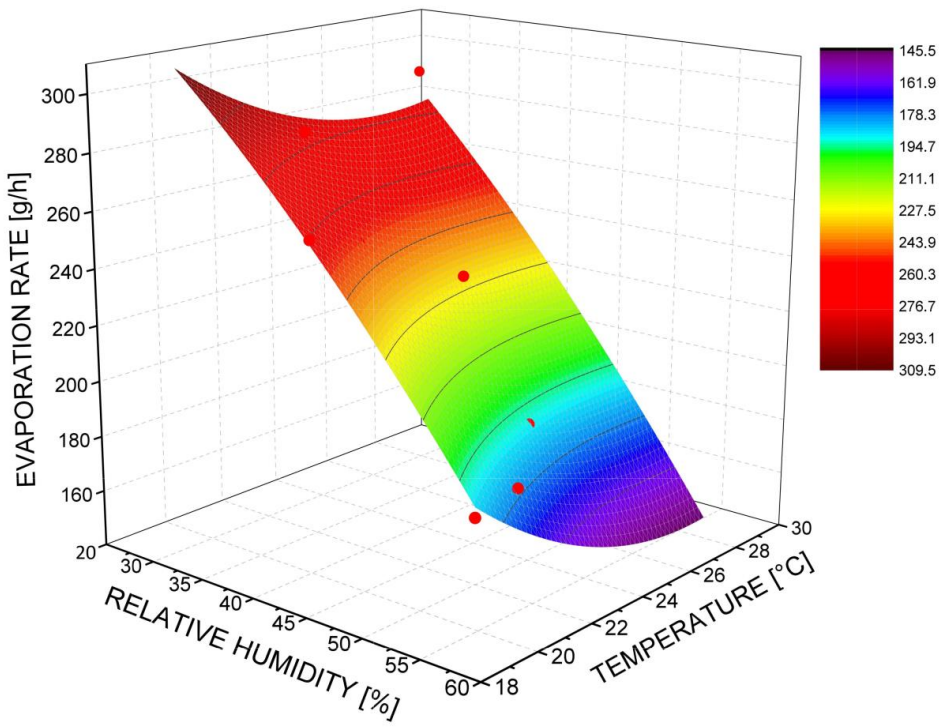

(b)

Figure 11. 3D scatter plot: (a) spatial representation of individual measurements depending on relative humidity temperature and evaporation rate; (b) nonlinear surface fitting tool predicted by OriginPro 9.0 software.

Using the two-dimensional polynomial function of the nonlinear surface fitting tool (Figure 11b), it was possible to determine the general Equation (1) of the water wall evaporation capacity as follows:

$$
\mathrm{ER}=\mathrm{z} 0+\mathrm{a} \times \mathrm{RH}+\mathrm{b} \times \mathrm{T}+\mathrm{c} \times \mathrm{RH}^{2}+\mathrm{d} \times \mathrm{T}^{2}+\mathrm{f} \times \mathrm{RH} \times \mathrm{T},
$$

where ER is the evaporation rate $(\mathrm{g} / \mathrm{h}) ; \mathrm{z} 0, \mathrm{a}, \mathrm{b}, \mathrm{c}, \mathrm{d}$, and $\mathrm{f}$ are constants $(\mathrm{z} 0=730.15079$, $\mathrm{a}=-0.23285, \mathrm{~b}=-29.46344, \mathrm{c}=-0.03763, \mathrm{~d}=0.591444, \mathrm{f}=-0.05625)$; $\mathrm{RH}$ is relative humidity $(\%)$; and $\mathrm{T}$ is air temperature $\left({ }^{\circ} \mathrm{C}\right)$. The coefficient of determination $\left(\mathrm{R}^{2}\right)$ of the equation is 0.83088 .

The lowest percentage deviation between the measured and calculated evaporation rate is shown by the measurement No. 2 (boundary conditions $\mathrm{T}=19.2^{\circ} \mathrm{C}, \mathrm{RH}=42.4 \%$ ), specifically $0.64 \%$. Vice versa, the most significant difference between the measured and calculated evaporation rate is manifested by the measurement No. 8 (boundary conditions $\mathrm{T}=23.2{ }^{\circ} \mathrm{C}, \mathrm{RH}=45.9 \%$ ); this difference represents a percentage deviation of $10.48 \%$. The mean percentage deviation is $3.8 \%$. 
Table 4. Boundary conditions measured evaporation rate, absolute difference, and percentage deviation between measured and calculated evaporation rate.

\begin{tabular}{|c|c|c|c|c|c|c|c|c|c|c|c|c|c|c|}
\hline & \multicolumn{14}{|c|}{ Measurements } \\
\hline & 1 & 2 & 3 & 4 & 5 & 6 & 7 & 8 & 9 & 10 & 11 & 12 & 13 & 14 \\
\hline Temperature $\left({ }^{\circ} \mathrm{C}\right)$ & $\begin{array}{l}19.2 \\
\pm 0.1\end{array}$ & $\begin{array}{l}19.2 \\
\pm 0.8\end{array}$ & $\begin{array}{l}20.7 \\
\pm 0.7\end{array}$ & $\begin{array}{l}21.2 \\
\pm 1.6\end{array}$ & $\begin{array}{l}21.7 \\
\pm 0.1\end{array}$ & $\begin{array}{l}21.8 \\
\pm 0.3\end{array}$ & $\begin{array}{l}22.1 \\
\pm 0.3\end{array}$ & $\begin{array}{l}23.2 \\
\pm 0.5\end{array}$ & $\begin{array}{l}23.7 \\
\pm 1.4\end{array}$ & $\begin{array}{l}24.1 \\
\pm 0.1\end{array}$ & $\begin{array}{l}24.3 \\
\pm 0.7\end{array}$ & $\begin{array}{l}25.8 \\
\pm 0.1\end{array}$ & $\begin{array}{l}27.4 \\
\pm 0.3\end{array}$ & $\begin{array}{l}28.3 \\
\pm 0.7\end{array}$ \\
\hline Relative humidity (\%) & $\begin{array}{l}56.6 \\
\pm 2.6\end{array}$ & $\begin{array}{l}42.4 \\
\pm 4.3\end{array}$ & $\begin{array}{l}41.0 \\
\pm 4.0\end{array}$ & $\begin{array}{l}36.4 \\
\pm 3.3\end{array}$ & $\begin{array}{l}54.4 \\
\pm 2.1\end{array}$ & $\begin{array}{l}38.8 \\
\pm 3.7\end{array}$ & $\begin{array}{l}39.2 \\
\pm 3.9\end{array}$ & $\begin{array}{l}45.9 \\
\pm 2.9\end{array}$ & $\begin{array}{l}34.8 \\
\pm 3.3\end{array}$ & $\begin{array}{l}49.7 \\
\pm 2.0\end{array}$ & $\begin{array}{l}37.8 \\
\pm 4.0\end{array}$ & $\begin{array}{l}48.4 \\
\pm 2.1\end{array}$ & $\begin{array}{l}31.3 \\
\pm 2.7\end{array}$ & $\begin{array}{l}30.0 \\
\pm 2.3\end{array}$ \\
\hline $\begin{array}{l}\text { Measurement: ER } \\
(\mathrm{g} / \mathrm{h})\end{array}$ & 184.11 & 260.77 & 246.75 & 287.54 & 180.97 & 244.11 & 249.38 & 240.32 & 255.05 & 188.89 & 235.84 & 188.25 & 293.87 & 271.23 \\
\hline Equation: ER (g/h) & 187.59 & 259.10 & 253.54 & 269.29 & 179.16 & 255.76 & 252.45 & 215.12 & 26424 & 191.46 & 249.33 & 194.18 & 274.65 & 281.22 \\
\hline Absolute difference & 3.48 & 1.67 & 6.79 & 18.25 & 1.81 & 11.65 & 3.07 & 25.20 & 9.19 & 2.57 & 13.49 & 5.93 & 19.22 & 9.99 \\
\hline Percent deviation (\%) & 1.89 & 0.64 & 2.75 & 6.35 & 1.00 & 4.77 & 1.23 & 10.48 & 3.60 & 1.36 & 5.72 & 3.15 & 6.54 & 3.68 \\
\hline
\end{tabular}

The determined equation obtained from experimental measurements can be used to calculate the humidifying effect for different boundary conditions, as the water element is intended to help to achieve an ideal level of humidity. The water wall has not been tested for higher humidity when its effect on the environment would be considered negative. Figure 12 shows the relative range of the evaporation rate and boundary conditions in which the results and determined equation still apply. The red line indicates the range of boundary conditions that were tested experimentally in the climate chamber.

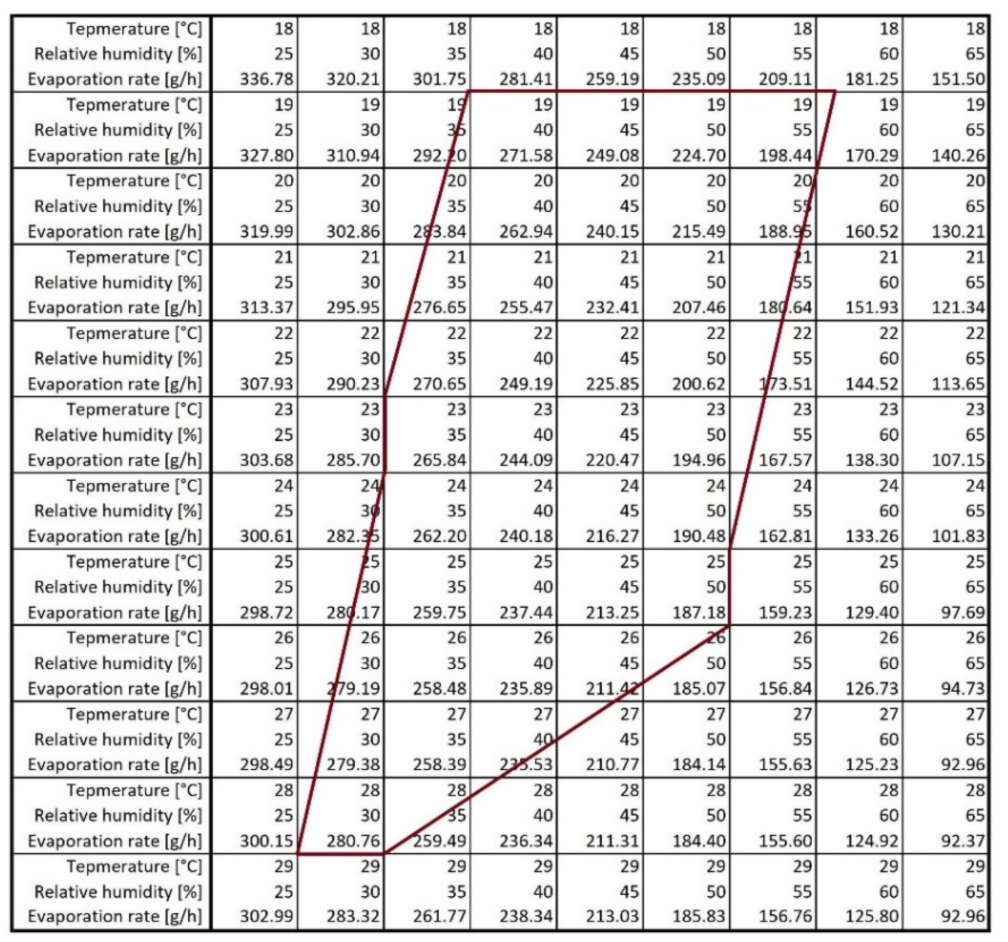

Figure 12. Evaporation rate of water wall with an area of $1 \mathrm{~m}^{2}$ for the selected temperature and relative humidity using determined Equation (1).

\section{Scenario 3}

In the case of a virtual water wall application, the same area of the water wall as the area of the living wall, i.e., $5 \mathrm{~m}^{2}$, is considered. For the virtual application of the water wall in space, the determined Equation (1) and the measured data from Sensor 2B of Scenario 2 are used. The humidity ratio is determined according to the relation:

$$
\chi=0.622 \frac{\mathrm{RH} \times \mathrm{p}_{\mathrm{w}}{ }^{\prime \prime}}{\mathrm{p}-\mathrm{RH} \times \mathrm{p}_{\mathrm{w}}{ }^{\prime \prime}}
$$


where $\mathrm{p}_{\mathrm{w}}$ " is partial pressure of saturated water vapor, calculated on the basis of:

$$
\mathrm{p}_{\mathrm{w}}{ }^{\prime \prime}=610.78 \times \mathrm{e}^{\frac{17.269 \times \mathrm{T}}{\mathrm{T}+237.3}}
$$

To calculate the effect of the water wall in the space, the air volume of $61.3 \mathrm{~m}^{3}$ and the air density of $1.2 \mathrm{~kg} / \mathrm{m}^{3}$ are considered. The mean calculated humidification capacity of the water wall is $1128.94 \mathrm{~g} / \mathrm{h}$, which caused an increase in the mean humidity ratio from $7.5 \mathrm{~g} / \mathrm{kg}$ (Scenario 2) to $8.8 \mathrm{~g} / \mathrm{kg}$. The maximum and minimum humidity ratios are 10 and $7 \mathrm{~g} / \mathrm{kg}$, respectively. By applying the water wall, the mean relative humidity increased by $7.4 \%$ to $51.8 \%$. The maximum and minimum relative humidity are $58.7 \%$ and $42 \%$, respectively. Similarly to the previous scenarios, the data from 8:00 to 10:00 are not considered in the overall assessment. It can be seen in Figure 13 that relative humidity does not exceed $60 \%$.

In the case of Scenario 3, only the change of the water vapor content in the air by the action of the water wall in the interior is considered; the change in temperature by the action of the water wall is not considered, and for this reason it is not shown in Figure 13. The difference represents the increment caused by the action of the water wall.

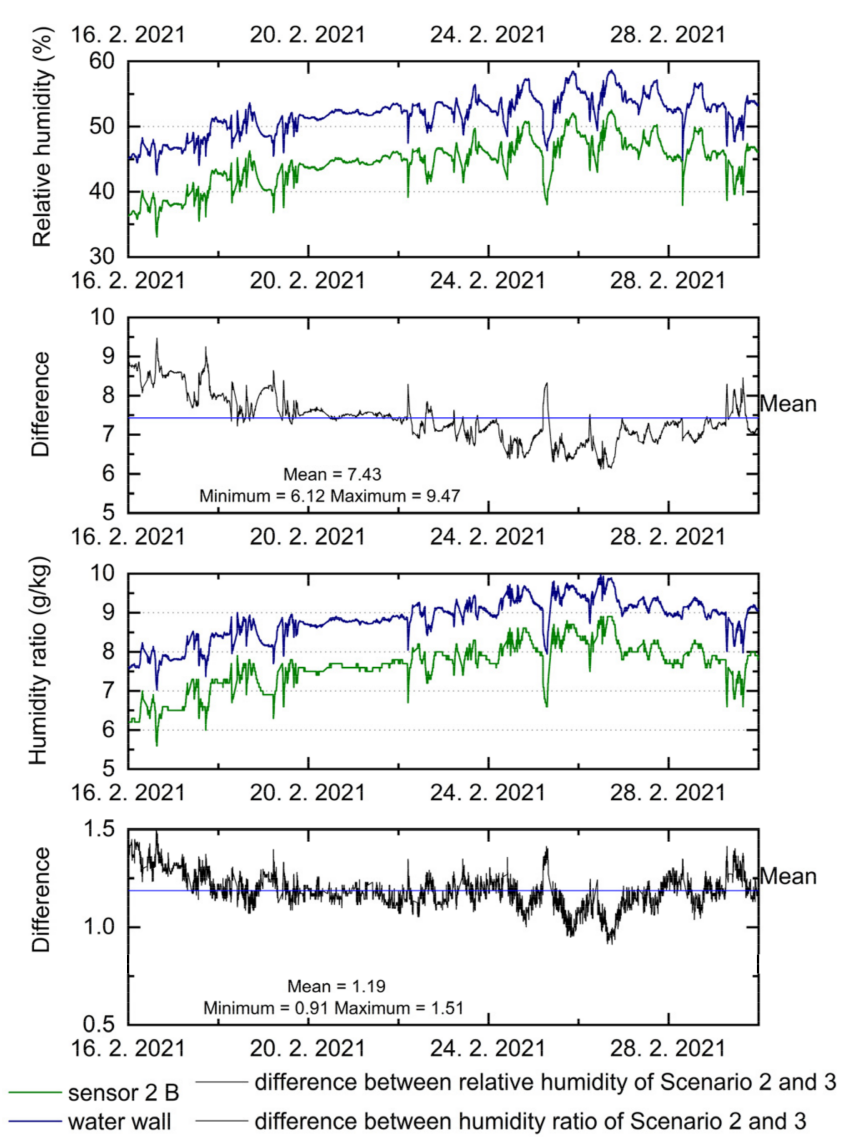

Figure 13. Course of selected physical parameters for Scenario 3, where sensor curve 2B shows measured data from Scenario 2.

\subsection{Water Consumption}

During the selected period of 29 days, a total of 11 irrigation cycles of the living wall were performed, which is approximately one irrigation cycle every 3 days. The amount of water for individual cycles is not the same and varies in the range of 8.4 to $15.2 \mathrm{~L}$. The average water consumption per irrigation cycle is $11.25 \mathrm{~L}$. A total of $123.7 \mathrm{~L}$ of water was consumed, which represents $0.85 \mathrm{~L} / \mathrm{m}^{2}$ per day. In the case of a water wall, the water consumption is proportional to the amount of evaporated water. With a water wall area of 
$5 \mathrm{~m}^{2}$, using the Equation (1) and measured data from Scenario 2, the average amount of evaporated water per hour is $1128.98 \mathrm{~g} / \mathrm{h}$. In 14 days, $380.26 \mathrm{~L}$ would be consumed, which represents $5.42 \mathrm{~L} / \mathrm{m}^{2}$ per day.

Previous studies have shown higher water consumption of green and living walls. Fernández-Cañero et al. [43] examined the water consumption of an indoor living wall for different types of substrates, and the study was performed experimentally in a warm climate. Their results show a different water consumption during June (the warmest period during the measurements) in the range of 3 to $5 \mathrm{~L} / \mathrm{m}^{2}$ per day, depending on the substrate used. A review of European living wall installations conducted by Gunawardena and Steemers [63] shows that a 6-day average water consumption during winter was in the range of $1.37-1.55 \mathrm{~L} / \mathrm{m}^{2}$ per day.

In this case, the lower consumption may be caused not only by winter conditions but also by the irrigation system and the method of growing plants, which is described in Section 2.2.3. There is no waste of water during the irrigation process, and the excess water is drained back into the water tank. In the case of the water wall, the consumption is higher than in the living wall, but this ensured that the minimum relative humidity did not fall below $40 \%$.

\subsection{Comparison of Scenarios}

Achieving the required thermal comfort in the building is essential for meeting the needs of occupants and the satisfaction level of indoor environmental quality. Although the greater emphasis is placed on achieving a satisfactory air temperature [64], it is equally important to achieve a satisfactory indoor humidity level, which consumes about $10-15 \%$ of the total energy consumed by the building [65]. Low or high levels of humidity in the building are associated with various sick building symptoms, bacteria, fungi, and virus risk. The relative humidity must therefore be within a certain defined range to achieve a positive health effect. In 1985, Sterling et al. [66] defined the range between $40-60 \%$ as the optimal comfortable relative humidity. A regulation of Government of the Czech Republic No. 361/2007 Coll. [67] extends this range and considers relative humidity at work in the range of $30-70 \%$ to be satisfactory. The government regulation sets the conditions for health protection at work with minimal whole-body physical activity (office administrative work, work with PC, laboratory work, etc.) and orders the minimum workplace temperature to be $20{ }^{\circ} \mathrm{C}$, with the optimum temperature at $22{ }^{\circ} \mathrm{C}$. However, in some cases, even when the required level of humidity resulting from the government regulation was reached, the occupants felt dissatisfied with the humidity, which manifested itself as dry or sore throat and itching, burning, or irritation to the eyes [68].

The resulting measured and calculated values of physical parameters are evaluated based on the ASHRAE Standard 55-2010 [69] that specifies conditions for acceptable thermal comfort during the heating season. As the living wall is located at university premises, when defining the comfort zone, a metabolic rate of 1.1 met is applied, which corresponds to light physical work, such as computer work. Clothing insulation is set at 1.0 clo; this insulation level is typical for clothing worn when the outdoor environment is cool. Figure 14 shows individual points of the scenarios in relation to the thermal comfort zone according to the ASHRAE Standard 55. A total of 3696 points are evaluated for each scenario, which are obtained from sensor 2B for Scenarios 1 and 2 and calculated for Scenario 3, respectively. The evaluation does not take into account the values measured between 8:00 and 10:00 a.m. As can be seen from the graphical solution of the thermal comfort zone, most points belong to the area of the comfort zone according to the ASHRAE Standard 55-2010; specifically regarding Scenario 1, it is $98.6 \%$; regarding Scenario 2, it is $99.8 \%$; and regarding Scenario 3 , it is $99.6 \%$ of the time. Thus, thermal comfort is unsatisfactory at a negligible level for all three scenarios. If the results of the relative humidity are evaluated based on the recommended range of $40-60 \%$, Scenario 1 is completely unsatisfactory, and the level of relative humidity is always lower than $40 \%$. By closing the space (Scenario 2), humidity is lower than $40 \%$ only $13.5 \%$ of the time. The presence of a water wall in the interior 
(Scenario 3) eliminates this problem, and the relative humidity does not fall below $40 \%$. At the same time, the recommended upper limit of $60 \%$ was not exceeded. The resulting values of relative humidity in Scenario 3 are not taken into account for the sorption capacity of the surrounding materials, and it can be assumed that in the real application of the water wall, the relative humidity would be even lower, and thus the water wall with the area of $5 \mathrm{~m}^{2}$ is suitable for the selected room with the volume considered in this study. The assessment of the relative humidity level based on the regulation of the Government of the Czech Republic (range 30-70\%) shows that Scenario 1 (semi-open space) does not meet this regulation $37.2 \%$ of the time. Scenarios 2 and 3 fully meet this regulation. As for the minimum temperature requirement based on the regulation of the Government of the Czech Republic, the scenarios fully meet this requirement, and the minimum air temperature is not lower than $20^{\circ} \mathrm{C}$.

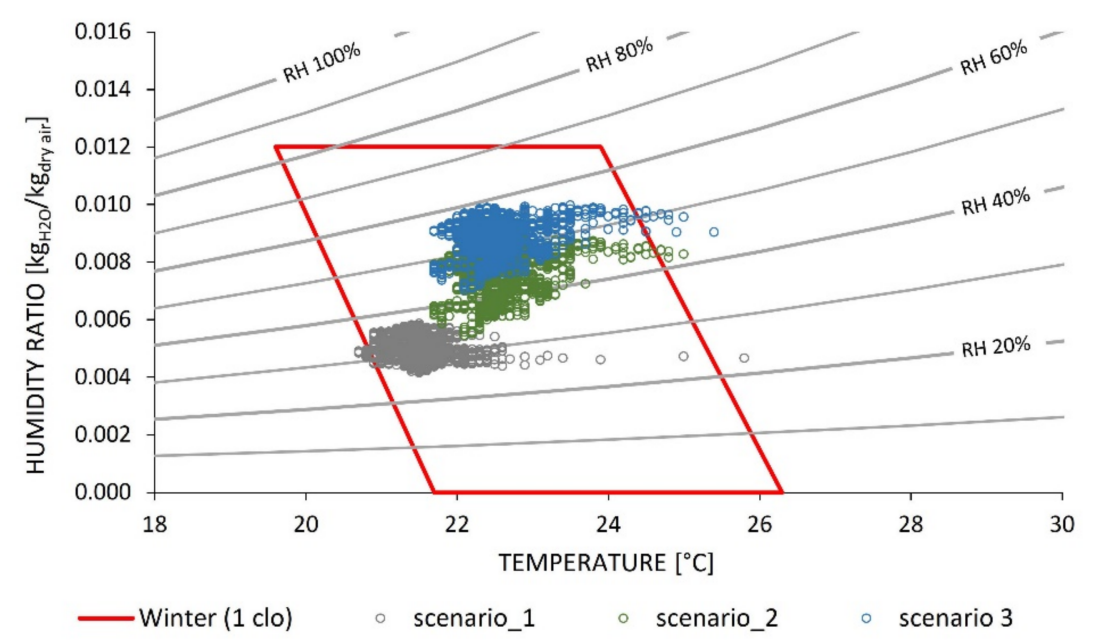

Figure 14. Displaying evaluated points for each scenario and graphic illustration of an acceptable range of temperature and humidity for spaces that meet criteria specified according to ASHRAE Standard 55-2010.

\section{Conclusions and Outlook}

The presented case study deals with the combination of in situ measurement with the influence of the vegetation wall on the physical parameters of the air and the virtual application of the water wall based on laboratory measurements. As the vegetation wall was applied in a specific space of the historic building, it was not possible to regulate the initial boundary conditions; the given space had its specifics such as space geometry, orientation, windows, and surface materials. The obtained results show that for effective and comprehensive use of vegetation elements in the interior with the aim of a positive impact on the indoor microclimate parameters, it is necessary to consider their use concerning the indoor space.

Because the performed in situ measurements had their limitations and variables that could not be removed and regulated, in terms of experimentation with water and vegetation elements, it seems reasonable that further research will be carried out in an artificially environment (test chamber), which should be characterized as follows:

- the surface temperature of the surrounding surfaces is the same;

- the sorption (desorption) capacity of the surrounding surfaces is known, and resp. testing is performed on sorption-inactive surfaces;

- the exchange and parameters of the air supplied to the test room are known.

The results obtained from future regulated and controlled measurements will be used to create a numerical model in a simulation tool, where it would be possible to evaluate various simulation scenarios. In addition to the standard physical and energy parameters, the requirements for the simulation software should include the possibility to specify the 
sorption/desorption capacity of the surfaces and to consider the mass moisture of the embedded materials as an initial condition.

Using validated numerical (simulation) experiments, it would be possible to determine:

- the optimal ratio of room volume and water/vegetation element;

- the impact of the presence of humans, animals, and their activities;

- the influence of different external climatic parameters;

- the influence of building envelope thermal quality;

- the influence of HVAC system; and

- the impact of moisture buffering effect and others.

The presented paper was created during an exchange stay within the project CZ.02.2.69 /0.0/0.0/18_053/0016962 "International mobility of researchers at Brno University of Technology II". Natural elements represented by living and water walls are a solid and important part of the indoor environment, where they have a positive effect on people's well-being. Therefore, it is necessary to further develop and deepen this issue in terms of the impact on the physical parameters of the indoor environment.

Author Contributions: Conceptualization, K.C. and D.B.; methodology, K.C. and M.V.; software, K.C., J.V. and O.N.; validation, K.C., M.V. and D.B.; formal analysis, K.C. and M.V.; investigation, K.C.; resources, K.C.; data curation, K.C.; writing_original draft preparation, K.C. and M.V.; writingreview and editing, K.C. and M.V.; visualization, K.C.; supervision, Z.V.; project administration, A.R., J.P. and Z.V.; funding acquisition, J.P. and Z.V. All authors have read and agreed to the published version of the manuscript.

Funding: This research received no external funding.

Institutional Review Board Statement: Not applicable.

Informed Consent Statement: Not applicable.

Data Availability Statement: All data are presented in this article in the form of figures and tables.

Acknowledgments: The authors are extremely grateful for the support of the Technology Agency of the Czech Republic FV40357 "Research and development of new building material consisting of a composite sandwich plate for vegetative vertical constructions at TOPWET company" and the Slovak Research and Development Agency APVV-18-0360 "Active hybrid infrastructure closer to a sponge city".

Conflicts of Interest: The authors declare no conflict of interest.

\section{References}

1. Fong, K.C.; Hart, J.E.; James, P. A review of epidemiologic studies on greenness and health: Updated literature through 2017. Curr. Environ. Health Rep. 2018, 5, 77-87. [CrossRef]

2. Nieuwenhuijsen, M.J.; Khreis, H.; Triguero-Mas, M.; Gascon, M.; Dadvand, P. Fifty shades of green: Pathway to healthy urban living. Epidemiology 2017, 28, 63-71. [CrossRef]

3. Gascon, M.; Triguero-Mas, M.; Martinez, D.; Dadvand, P.; Forns, J.; Plasencia, A.; Nieuwenhuijsen, M.J. Mental health benefits of long-term exposure to residential green and blue spaces: A systematic review. Int. J. Environ. Res. Public Health 2015, 12, 4354-4379. [CrossRef] [PubMed]

4. James, P.; Banay, R.F.; Hart, J.E.; Laden, F. A review of the health benefits of greenness. Curr. Epidemiol. Rep. 2015, 2, 131-142. [CrossRef]

5. Gascon, M.; Triguero-Mas, M.; Martinez, D.; Dadvand, P.; Rojas-Rueda, D.; Plasència, A.; Nieuwenhuijsen, M.J. Residential green spaces and mortality: A systematic review. Environ. Int. 2016, 86, 60-67. [CrossRef]

6. Dadvand, P.; Bartoll, X.; Basagana, X.; Dalmau-Bueno, A.; Martinez, D.; Ambros, A.; Cirach, M.; Triguero-Mas, M.; Gascon, M.; Borrell, C.; et al. Green spaces and general health: Roles of mental health status, social support, and physical activity. Environ. Int. 2016, 91, 161-167. [CrossRef]

7. Gong, Y.; Palmer, S.; Gallacher, J.; Marsden, T.; Fone, D. A systematic review of the relationship between objective measurements of the urban environment and psychological distress. Environ. Int. 2016, 96, 48-57. [CrossRef] [PubMed]

8. Van Ryswyk, K.; Prince, N.; Ahmed, M.; Brisson, E.; Miller, J.D.; Villeneuve, P.J. Does urban vegetation reduce temperature and air pollution concentrations? Findings from an environmental monitoring study of the Central Experimental Farm in Ottawa, Canada. Atmos. Environ. 2019, 218, 116886. [CrossRef]

9. Dzhambov, A.M.; Dimitrova, D.D. Urban green spaces' effectiveness as a psychological buffer for the negative health impact of noise pollution: A systematic review. Noise Health 2014, 16, 157-165. [CrossRef] [PubMed] 
10. Manteghi, G.; Bin Limit, H.; Remaz, D. Water bodies an urban microclimate: A review. Mod. Appl. Sci. 2015, 9, 1-12. [CrossRef]

11. White, M.P.; Elliott, L.R.; Taylor, T.; Wheeler, B.W.; Spencer, A.; Bone, A.; Depledge, M.H.; Fleming, L.E. Recreational physical activity in natural environments and implications for health: A population based cross-sectional study in England. Prev. Med. 2016, 91, 383-388. [CrossRef]

12. Gascon, M.; Zijlema, W.; Vert, C.; White, M.P.; Nieuwenhuijsen, M.J. Outdoor blue spaces, human health and well-being: A systematic review of quantitative studies. Int. J. Hyg. Environ. Health 2017, 220, 1207-1221. [CrossRef]

13. Völker, S.; Kistemann, T. The impact of blue space on human health and well-being-Salutogenetic health effects of inland surface waters: A review. Int. J. Hyg. Environ. Health 2011, 214, 449-460. [CrossRef] [PubMed]

14. De Bell, S.; Graham, H.; Jarvis, S.; White, P. The importance of nature in mediating social and psychological benefits associated with visits to freshwater blue space. Landsc. Urban Plan. 2017, 167, 118-127. [CrossRef]

15. Poórová, Z.; Vranayová, Z. Green Roofs and Water Retention in Košice, Slovakia, 1st ed.; Springer Nature: Cham, Switzerland, 2020; pp. 59-67. [CrossRef]

16. Yang, G.; Yu, Z.; Jørgensen, G.; Vejre, H. How can urban blue-green space be planned for climate adaption in high-latitude cities? A seasonal perspective. Sustain. Cities Soc. 2020, 53, 101932. [CrossRef]

17. Nastran, M.; Kobal, M.; Eler, K. Urban heat islands in relation to green land use in European cities. Urban For. Urban Green. 2019, 37, 33-41. [CrossRef]

18. Dwivedi, A.; Mohan, B.K. Impact of green roof on micro climate to reduce Urban Heat Island. Remote Sens. Appl. Soc. Environ. 2018, 10, 56-69. [CrossRef]

19. Shi, D.; Song, J.; Huang, J.; Zhuang, C.; Guo, R.; Gao, Y. Synergistic cooling effects (SCEs) of urban green-blue spaces on local thermal environment: A case study in Chongqing, China. Sustain. Cities Soc. 2020, 55, 102065. [CrossRef]

20. Steeneveld, J.G.; Koopmans, S.; Heusinkveld, G.B.; Theeuwes, E.N. Refreshing the role of open water surfaces on mitigating the maximum urban heat island effect. Landsc. Urban Plan. 2014, 121, 92-96. [CrossRef]

21. United Nations, Department of Economic and Social Affairs, World Urbanization Prospects: The 2018 Revision. United Nations New York. 2019. Available online: https:/ / population.un.org/wup/Publications/Files/WUP2018-Report.pdf (accessed on 25 June 2021).

22. Coburn, A.; Vartanian, O.; Kenett, N.Y.; Nadal, M.; Hartung, F.; Hayn-Leichsenring, G.; Navarrete, G.; González-Mora, L.J.; Chatterjee, A. Psychological and neural responses to architectural interiors. Cortex 2020, 126, 217-241. [CrossRef]

23. Rebrova, T.; Beckovsky, D.; Selnik, P. Monitoring of the Green Roofs Installation in Brno-City District, Czech Republic. IOP Conf. Ser. Earth Environ. Sci. 2017, 95, 042040. [CrossRef]

24. Hami, A.; Moula, A.A.; Maulan, S.B. Public preferences toward shopping mall interior landscape design in Kuala Lumpur, Malaysia. Urban For. Urban Green. 2018, 30, 1-7. [CrossRef]

25. Choi, J.-Y.; Park, S.-A.; Jung, S.-J.; Lee, J.-Y.; Son, K.-C.; An, Y.J.; Lee, S.-W. Physiological and psychological responses of humans to the index of greenness of an interior space. Complement. Ther. Med. 2016, 28, 37-43. [CrossRef]

26. Mcsweeney, J.; Rainham, D.; Johnson, S.A.; Sherry, S.B.; Singleton, J.J. Indoor nature exposure (INE): A health-promotion framework. Health Promot. Int. 2015, 30, 126-139. [CrossRef] [PubMed]

27. Horr, Y.A.; Arif, M.; Kaushik, A.; Mazroei, A.; Katafygiotou, M.; Elsarrag, E. Occupant productivity and office indoor environment quality: A review of the literature. Build. Environ. 2016, 105, 369-389. [CrossRef]

28. van den Bogerd, N.; Dijkstra, S.C.; Tanja-Dijkstra, K.; de Boer, M.R.; Seidell, J.C.; Koole, S.K.; Maas, J. Greening the classroom: Three field experiments on the effects of indoor nature on students' attention, well-being, and perceived environmental quality. Build. Environ. 2020, 171, 106675. [CrossRef]

29. van den Berg, A.E.; Wesselius, J.E.; Maas, J.; Tanja-Dijkstra, K. Green Walls for a Restorative Classroom Environment: A Controlled Evaluation Study. Environ. Behav. 2016, 49, 791-813. [CrossRef]

30. Park, S.-H.; Mattson, R.H. Therapeutic Influences of Plants in Hospital Rooms on Sur-gical Recovery. HortScience 2009, 44, 102-105. [CrossRef]

31. Bringslimark, T.; Hartig, T.; Patil, G.G. The psychological benefits of indoor plants: A critical review of the experimental literature. J. Environ. Psychol. 2009, 29, 422-433. [CrossRef]

32. Kellert, S.R.; Heerwagen, J.; Mador, M. Biophilic Design: The Theory, Science and Practice of Bringing Buildings to Life; John Wiley \& Sons: Hoboken, NJ, USA, 2011.

33. Pérez-Urrestarazu, L.; Kaltsidi, M.P.; Nektarios, P.A.; Markakis, G.; Loges, V.; Perini, K.; Fernández-Cañero, R. Particularities of having plants at home during the confinement due to the COVID-19 pandemic. Urban For. Urban Green. 2021, $59,126919$. [CrossRef]

34. Gunawardena, K.; Steemers, K. Living walls in indoor environments. Build. Environ. 2019, 148, 478-487. [CrossRef]

35. Charoenkit, S.; Yiemwattana, S. Living walls and their contribution to improved thermal comfort and carbon emission reduction: A review. Build. Environ. 2016, 105, 82-94. [CrossRef]

36. Wang, C.; Er, S.-S.; Abdul-Rahman, H. Indoor vertical greenery system in urban tropics. Indoor Built Environ. 2016, 25, 340-356. [CrossRef]

37. Franco, A.; Fernández-Cañero, R.; Pérez-Urrestarazu, L.; Valera, D.L. Wind tunnel analysis of artificial substrates used in active living walls for indoor environment conditioning in Mediterranean buildings. Build. Environ. 2012, 51, 370-378. [CrossRef] 
38. Pérez-Urrestarazu, L.; Fernández-Cañero, R.; Franco, A.; Egea, G. Influence of an active living wall on indoor temperature and humidity conditions. Ecol. Eng. 2016, 90, 120-124. [CrossRef]

39. Moya, A.T.; van den Dobbelsteen, A.; Ottele', M.; Bluyssen, M.P. A review of green systems within the indoor environment. Indoor Built Environ. 2019, 28, 298-309. [CrossRef]

40. Tudiwer, D.; Korjenic, A. The effect of an indoor living wall system on humidity, mould spores and $\mathrm{CO}_{2}$-concentration. Energy Build. 2017, 146, 73-86. [CrossRef]

41. Poórová, Z.; Turcovská, A.; Kapalo, P.; Vranayová, Z. The Effect of Green Walls on Humidity, Air Temperature, $\mathrm{Co}_{2}$ and Well-Being of People. Environ. Sci. Proc. 2020, 2, 56. [CrossRef]

42. Hollands, J.; Korjenic, A. Indirect Economic Effects of Vertical Indoor Green in the Context of Reduced Sick Leave in Offices. Sustainability 2021, 13, 2256. [CrossRef]

43. Fernández-Cañero, R.; Urrestarazu, L.P.; Franco Salas, A. Assessment of the Cooling Potential of an Indoor Living Wall using Different Substrates in a Warm Climate. Indoor Built Environ. 2012, 21, 642-650. [CrossRef]

44. Cakyova, K.; Vranay, F.; Vertal, M.; Vranayova, Z. Determination of Dehumidification Capacity of Water Wall with Controlled Water Temperature: Experimental Verification under Laboratory Conditions. Sustainability 2021, 13, 5684. [CrossRef]

45. $\mathrm{Wu}, \mathrm{T}$; Lei, C. A review of research and development on water wall for building applications. Energy Build. 2016, 112, 198-208. [CrossRef]

46. Chen, W.; Liu, S.; Lin, J. Analysis on the passive evaporative cooling wall constructed of porous ceramic pipes with water sucking ability. Energy Build. 2015, 86, 541-549. [CrossRef]

47. Tewari, P.; Mathur, S.; Mathur, J. Thermal performance prediction of office buildings using direct evaporative cooling systems in the composite climate of India. Build. Environ. 2019, 157, 64-78. [CrossRef]

48. Moosavi, L.; Mahyuddin, N.; Ghafar, N. Atrium cooling performance in a low energy office building in the Tropics, a field study. Build. Environ. 2015, 94, 384-394. [CrossRef]

49. Mitterer, C. Cooling and Dehumidifying Indoor Environments Using the Chilled Water Wall; IBP-FRAUNHOFER: Valley, Germany. Available online: https://www.ibp.fraunhofer.de/content/dam/ibp/en/documents/Information-material/Departments / Hygrothermics/Produktblaetter/IBP_255_PB_Klimabrunnen_neu_en_rz_web.pdf (accessed on 25 June 2021).

50. Fang, Y.-M.; Lee, J.M.C.; Mitterer, C.; Kunzel, M.H. The performance of heat pump integrated with chilled water wall for air conditioning and domestic hot water. IOP Conf. Ser. Earth Environ. Sci. 2019, 294, 012032. [CrossRef]

51. Cakyova, K.; Vranay, F.; Vranayova, Z. Using water wall like air humidifier. Sel. Sci. Pap.-J. Civ. Eng. 2020, 15, 13-18. [CrossRef]

52. Haupt, T.E.; Heffernan, T.R.; Kazmierczak, J.J.; Nehls-Lowe, H.; Rheineck, B.; Powell, C.; Leonhardt, K.K.; Chitnis, S.A.; Davis, P.J. An Outbreak of Legionnaires Disease Associated with a Decorative Water Wall Fountain in a Hospital. Infect. Control Hosp. Epidemiol. 2012, 33, 185-191. [CrossRef]

53. Kottek, M.; Grieser, J.; Beck, C.; Rudolf, B.; Rubel, F. World Map of the Köppen-Geiger climate classification updated. Meteorol. Z. 2006, 15, 259-263. [CrossRef]

54. Skalák, P.; Farda, A.; Zahradníček, P.; Trnka, M.; Hlásny, T.; Štěpánek, P. Projected shift of Köppen-Geiger zones in the central Europe: A first insight into the implications for ecosystems and the society. Int. J. Climatol. 2018, 38, 3595-3606. [CrossRef]

55. Czech Hydrometeorological Institute, Historical Data. Available online: https://www.chmi.cz/historicka-data/pocasi/mesicnidata/mesicni-data-dle-z.-123-1998-Sb (accessed on 25 June 2021).

56. Kraus, M. Hygrothermal Analysis of Indoor Environment of Residential Prefabricated Buildings. IOP Conf. Ser. Mater. Sci. Eng. 2017, 245, 042071. [CrossRef]

57. Wolkoff, P. Indoor air humidity, air quality, and health-An overview. Int. J. Hyg. Environ. Health 2018, 221, 376-390. [CrossRef] [PubMed]

58. TUBO, METEO DATA. Available online: http://tubo.fce.vutbr.cz/new/meteoExport.asp (accessed on 25 June 2021).

59. Flora Urbanica, Green Wall System. Available online: https:/ / floraurbanica.com/en/flora-panel/ (accessed on 25 June 2021).

60. Čákyová, K.; Vranay, F. Utility Model Number 8710: Water Wall Collection Container with Overflow Edge (Zberná Nádoba Vodnej Steny s Prepadovou Hranou); Industrial Property Office of the Slovak Republic: Banská Bystrica, Slovak Republic, 2019. Available online: https:/ / wbr.indprop.gov.sk/WebRegistre/UzitkovyVzor/Detail/50129-2017 (accessed on 25 June 2021).

61. Č́ákyová, K.; Vranay, F.; Kušnír, M. Impact of Flow Rate To Water Film Thickness of Water Wall. Advances and Trends in Engineering Sciences and Technologies III; CRC Press: London, UK, 2019; pp. 337-342. [CrossRef]

62. Gunawardena, K.R.; Steemers, K. Living wall influence on microclimates: An indoor case study. J. Phys. Conf. Ser. 2019, 1343, 012188. [CrossRef]

63. Gunawardena, K.; Steemers, K. Urban living walls: Reporting on maintenance challenges from a review of European installations. Archit. Sci. Rev. 2020, 63, 526-535. [CrossRef]

64. Dolnikova, E.; Katunsky, D.; Vertal, M.; Zozulak, M. Influence of Roof Windows Area Changes on the Classroom Indoor Climate in the Attic Space: A Case Study. Sustainability 2020, 12, 5046. [CrossRef]

65. Qi, R.; Dong, C.; Zhang, L.-Z. A review of liquid desiccant air dehumidification: From system to material manipulations. Energy Build. 2020, 215, 109897. [CrossRef]

66. Sterling, E.M.; Arundel, A.; Sterling, T.D. Criteria for Human Exposure to Humidity in Occupied Buildings. ASHRAE Trans. 1985, 91, 611-622. 
67. Regulation of the Government of the Czech Republic No. 361/2007 Coll., Government Order Laying down Health and Safety Conditions at Work. Available online: https:/ / www.zakonyprolidi.cz/cs/2007-361 (accessed on 25 June 2021).

68. Vilcekova, S.; Meciarova, L.; Kridlova Burdova, E.; Katunska, J.; Kosicanova, D.; Doroudiani, S. Indoor environmental quality of classrooms and occupants' comfort in a special education school in Slovak Republic. Build. Environ. 2017, 120, 29-40. [CrossRef]

69. ASHRAE Standard 55. Thermal Environmental Conditions for Human Occupancy; American Society of Heating, Refrigerating and Air-Conditioning Engineering, Inc.: Atlanta, GA, USA, 2010. 